\title{
Forest condition in the Congo Basin for the assessment of ecosystem conservation status
}

\author{
Aurélie C. Shapiro a,b, ${ }^{\text {, }}$, Hedley S. Grantham ${ }^{\text {c }}$, Naikoa Aguilar-Amuchastegui ${ }^{\mathrm{d}}$, \\ Nicholas J. Murray ${ }^{\mathrm{e}}$, Valery Gond ${ }^{\mathrm{f}}$, Djoan Bonfils ${ }^{\mathrm{g}}$, Olivia Rickenbach ${ }^{\mathrm{h}}$ \\ ${ }^{\text {a } W W F-G e r m a n y ~ S p a c e+S c i e n c e, ~ R e i n h a r d t s t r . ~ 18, ~} 10117$ Berlin, Germany \\ ${ }^{\mathrm{b}}$ Geography Department, Humboldt-Universität-zu-Berlin, Berlin, Germany \\ ${ }^{\mathrm{c}}$ Wildlife Conservation Society (WCS), Bronx, NY, USA \\ ${ }^{\mathrm{d}}$ Forest and Climate, WWF-US, Washington, DC, USA \\ e College of Science and Engineering, James Cook University, Townsville, Queensland, Australia \\ ${ }^{\mathrm{f}}$ Forêts et Sociétés, CIRAD, Montpellier, France \\ ${ }^{\mathrm{g}}$ World Resources Institute (WRI), Washington, DC, USA \\ ${ }^{\mathrm{h}}$ Forest Stewardship Council (FSC), Brazzaville, Congo
}

\section{A R T I C L E I N F O}

\section{Keywords:}

Monitoring

Forest degradation

Condition

Conservation planning

REDD+

Stratification

Red List

Prioritization

\begin{abstract}
A B S T R A C T
Quantifying ecological condition, notably the extent of forest degradation is important for understanding and designing measures to protect biodiversity and enhancing the capacity of forests to deliver ecosystem services. Conservation planning, particularly the prioritization of management interventions for forests, is often lacking spatial data on forest degradation, and it is often overlooked within decision-making processes. We develop a continuous metric termed Forest Condition (FC) which aims to measure the degree of forest degradation on a scale from 0 to 100, incorporating the temporal history of forest change over any spatial extent. We parameterize this metric based on estimated changes in above ground biomass in the context of forest fragmentation over time to estimate a continuous measure of forest degradation for Congo Basin countries. We estimate that just $<70 \%$ of Congo Basin forests remain fully intact, a decrease from $78 \%$ in the year 2000 . FC was validated by direct remote sensing measurements from Landsat imagery for DRC. Results showed that FC was significantly positively correlated with forest canopy cover, gap area per hectare, and magnitude of temporal change in Normalized Burn Ratio. We tested the ability of FC to distinguish primary and secondary degradation and deforestation and found significant differences in gap area and spectral anomalies to validate our theoretical model. We apply the IUCN Red List of Ecosystems criteria to demonstrate the integration of forest condition to assess the risk of ecosystem collapse. Based on this assessment, we found that without including FC in the assessment of biotic disruption, 12 ecosystems representing over $11 \%$ of forested area in 2015 would not have been assigned a threat status, and an additional 9 ecosystems would have a lower threat status. Our overall assessment of ecosystems found about half of all Congo Basin ecosystem types, accounting for $20 \%$ of all forest area are threatened to some degree, including 4 ecosystems ( $<1 \%$ of total area) which are critically engendered. FC is a transferrable and scalable assessment to support forest monitoring, planning, and management.
\end{abstract}

\section{Introduction}

Forest ecosystems provide essential ecosystem services to people, such as provision of food and materials, hydrological functions for clean supply of water, and home to numerous indigenous peoples (Díaz et al., 2019). They are also at the forefront of global initiatives for the mitigation of greenhouse gas emissions, as conserving remaining intact forests is important for carbon sequestration and avoidance of future potential emissions (Jantz et al., 2014; Maxwell et al., 2019; Mitchell et al., 2017). Forests harbour unique and important biodiversity which underpins many of these functions, aligning with conservation efforts (Feeley and Terborgh, 2005; Stokstad, 2014) and intact forest ecosystems are shown to have greater conservation benefits than degraded ones of similar ecological type (Betts et al., 2019; Haddad et al., 2015), making strong arguments for prioritizing them for conservation management (Watson et al., 2018).

\footnotetext{
* Corresponding author at: WWF-Germany Space+Science, Reinhardtstr. 18, 10117 Berlin, Germany.
} 
Despite this value, forests are increasingly threatened by expanding human activities (Thompson et al., 2011; Venter et al., 2016). The degradation of forest can occurs through a process of fragmentation, which in turn impacts biodiversity, biomass, and therefore the ability of forest to provide many ecosystem services (Betts et al., 2019; ChaplinKramer et al., 2015; Haddad et al., 2015; Potapov et al., 2012). Although there is no standard definition of forest degradation (Ghazoul et al., 2015; Potapov et al., 2009), it has been acknowledged that declines in forest intactness result in environmental and social problems which impact forest health, affecting human livelihoods and economic development (Foley et al., 2005; Pereira et al., 2010). Understanding and quantifying changes in forest fragmentation related to ecological condition is therefore crucial to monitor, manage and protect intact forests over time to prevent such problems (Brooks et al., 2006; Mittermeier et al., 2003). We define degradation via the term forest "condition" between a state of maximum intactness and completely deforested using a combination of spatial patterns of fragmentation and ecosystem services, notably above ground biomass (AGB) as described in (Shapiro et al., 2016).

Remote sensing can provide affordable, efficient, consistent multitemporal measurements for forest monitoring, and assessment of forest condition when appropriately defined (Mitchell et al., 2017). The recent increases in the reliable use of satellite technology, as well as improved access to data and enhanced processing capabilities, are promoting analyses of higher temporal resolution which enable improved assessments of forest degradation over time. Remote sensing approaches for forest degradation are generally grouped into direct and indirect approaches (Herold et al., 2011). There are advantages and disadvantages to each approach which will vary by geography, resources available, and specific needs. Direct remote sensing methods estimate parameters such as spectral indices related to canopy gaps and structure, changes in forest canopies, or productivity in time series (DeVries et al., 2015; Mitchell et al., 2017; Souza et al., 2005; Spruce et al., 2011; Verbesselt et al., 2012, 2010), although the implementation over a large area can be limited by image resolution or availability of time series or consistency between sensor types or climate effects (Cohen et al., 2010; Kennedy et al., 2010; Zhu, 2017) which can hinder the ability to compare variables in different geographies or climate regimes. Direct satellite measurements can also be affected by the complexity of defining degradation according to specific remote sensing indicators, and are more sensitive to forest dynamics, changes in vegetation, climate or even extreme events such as droughts, which may represent shorter term events which may be confused with degradation. In contrast, indirect methods employ the mapping of proxies, for example presence of roads, fires, forest edges or pattern (Broadbent et al., 2008; Chaplin-Kramer et al., 2015; Haddad et al., 2015; Potapov et al., 2008; Riitters et al., 2016; Shapiro et al., 2016; Tyukavina et al., 2016). These methods are particularly suitable for planning and monitoring, reporting and verification in developing countries with low field monitoring resources (Bucki et al., 2012). Fragmentation and spatial pattern approaches are conceptually simpler, and being increasingly used in the development of reference levels and targets for emissions reduction programs, for example in Nepal (Forest Carbon Partnership Facility (FCPF), 2018). Indirect methods do however have their own limitations, which include of oversimplifying degradation processes, may not be sensitive to small-scale changes, and relies heavily on the quality of underlying datasets such as forest cover (Herold et al., 2011; Miettinen et al., 2014).

There is a need for simple approaches for assessing and monitoring forest condition to provide a repeatable, transferrable and understandable indicator for regional conservation planning and prioritization for conservation, for example the intact forest landscape approach (Potapov et al., 2008), hinterland forests (Tyukavina et al., 2016), or the stratification approach from (Bucki et al., 2012). These binary assessments are based on the application of hard thresholds (which may vary by geography or landscape) to discern degraded forests from intact, although forest degradation is in reality, a gradient of disturbance or impacts over time (Sasaki and Putz, 2009). An indicator that provides a continuous estimation forest condition could therefore provide a finer representation of this temporal, cumulative process.

In this study, we build on previous research (Shapiro et al., 2016), to assess forest condition (FC) by developing analyses of key forest fragmentation and structure indicators over time. We first assess changes in forest spatial pattern, and then use available estimates of above-ground biomass (AGB) in strata defined by these spatial patterns to assign a continuous estimation of FC. FC is calculated by effects of fragmentation and increase in forest edges and associated impacts over time using relative changes in AGB. We apply a theoretical model to discern primary and secondary degradation from deforestation, and demonstrate how the results - a new forest condition metric - enable evaluations of the extent and severity of ecosystem degradation to assess forest ecosystem collapse under the IUCN Red List of Ecosystems categories and criteria (Bland et al., 2015; IUCN, 2016a; Rodríguez et al., 2015).

\section{Materials and methods}

\subsection{Study area}

The Congo Basin forest ecoregion (Olson and Dinerstein, 2002) is comprised of tropical forests in the Democratic Republic of Congo (DRC), Republic of Congo (ROC), Equatorial Guinea, Gabon, Cameroon, Central Africa Republic and a small portion of Angola (Fig. 1). This represents the largest connected tract of forest in Africa, and the single largest peatland complex in the world, storing a significant amount of forest carbon (Dargie et al., 2017). The basin is highly biodiverse and is a focus of recent species discovery (Dargie et al., 2019; Hart et al., 2012), while more than 30 million people inhabit the basin, including indigenous communities with a long and intricate relationship to natural ecosystems (Riddell, 2013). Together these characteristics represent a unique ecological opportunity to mitigate climate, while supporting the livelihoods of the many communities who depend on essential natural resources. The relative lack of current geo-spatial information on forests, and few validation information from the ground due to lack of access or security, political instability; or widely distributed studies on land-use related impacts on forests and associated species biodiversity, for example in compared to the Amazon basin or Asian forests currently hinders successful management and conservation efforts in the context of needed sustainable development (Malhi et al., 2013).

\subsection{Data sources}

We developed a comprehensive dataset of relevant ecological, physical and forest data layers to evaluate FC for Congo Basin forests, explained in Table 1. This includes the assessment of biogeographically distinct forest ecosystems, best available data on AGB, and validation data such as canopy height, gap area and fractional cover derived from LiDAR, and Landsat derived normalized burn ratio (NBR).

\subsubsection{Congo Basin forest ecosystems}

To develop the forest ecosystem map we applied a number of processing steps. First, we used forest cover data for terra firme forests from Philippon et al. (2018), which assessed phenology patterns and light regimes derived from MODIS (Moderate Resolution Imaging Spectrometer) to identify eight distinct forest types at $500 \mathrm{~m}$ resolution. To complete coverage of all forests in our study area we then identified open forests using data from Hansen et al. (2013), which were identified from treecover greater than 60\% (in 2000) and outside the MODIS derived map. We integrated mangroves mapped by Giri et al. (2011) and lastly, swamp forest types by overlaying data from two sources, (Betbeder et al., 2014) and (Dargie et al., 2017), which together identified 14 unique swamp forest types by flooding dynamics and dominant species (see supplemental material). We resampled our forest types data 


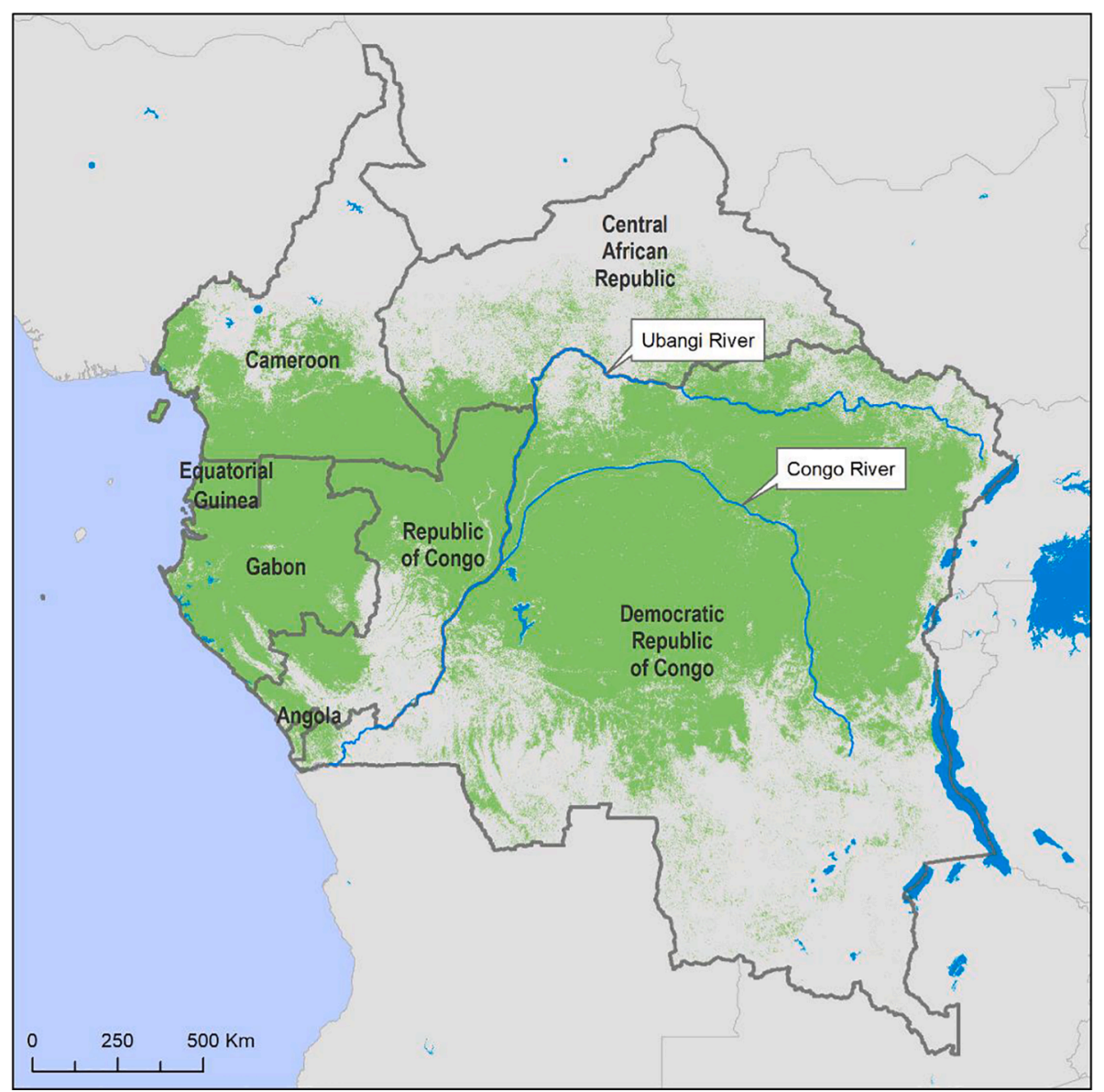

Fig. 1. The regional study area encompasses 6 countries in the Congo Basin. A national scale assessment focuses on the Democratic Republic of Congo (DRC). Major biogeographic boundaries are defined by the Ubangi and Congo Rivers. Green shows the primary tropical forest cover for 2016. (For interpretation of the references to color in this figure legend, the reader is referred to the web version of this article.)

to a common pixel resolution of 1 ha $(100 \mathrm{~m} \times 100 \mathrm{~m})$.

To better represent biogeographic patterns in forest types, we split our combined maps into regions defined by important bio-physical barriers which are known to have isolated distinct species (e.g. great

Table 1

Datasets and descriptions and relevant article section.

\begin{tabular}{|c|c|c|c|}
\hline Data & Source & Description & Section \\
\hline \multicolumn{4}{|l|}{ Data to derive FC } \\
\hline $\begin{array}{l}\text { Forest } \\
\text { Ecosystems }\end{array}$ & $\begin{array}{l}\text { Philippon } \\
\text { et al., } 2018 \\
\text { Hansen et al., } \\
2013 \\
\text { Giri et al., } \\
2011 \\
\text { Dargie et al., } \\
2017 \\
\text { Betbeder } \\
\text { et al., } 2014\end{array}$ & $\begin{array}{l}64 \text { unique forest types determined } \\
\text { by phenology, climate regime, } \\
\text { flooding dynamics and bio- } \\
\text { geographical zone }\end{array}$ & 2.2 .1 \\
\hline $\begin{array}{l}\text { Above Ground } \\
\text { Biomass (AGB) }\end{array}$ & $\begin{array}{l}\text { Xu et al., } \\
2017\end{array}$ & $\begin{array}{l}\text { National forest biomass dataset } \\
\text { derived from LiDAR and satellite } \\
\text { imagery for the DRC }\end{array}$ & 2.2 .2 \\
\hline \multicolumn{4}{|l|}{ Validation data } \\
\hline Canopy height & $\begin{array}{l}\text { Xu et al., } \\
2017\end{array}$ & $\begin{array}{l}\text { National airborne LiDAR dataset } \\
\text { for the DRC }\end{array}$ & 2.4 .1 \\
\hline Forest gap area & $\begin{array}{l}\text { Xu et al., } \\
2017\end{array}$ & $\begin{array}{l}\text { Derived from LiDAR canopy height } \\
\text { following method of Betts et al., } \\
2019\end{array}$ & 2.4 .2 \\
\hline Fractional cover & $\begin{array}{l}\text { Xu et al., } \\
2017\end{array}$ & $\begin{array}{l}\text { Derived from LiDAR forest canopy } \\
\text { height }\end{array}$ & 2.4 .3 \\
\hline $\begin{array}{l}\text { Normalized Burn } \\
\text { Ratio (NBR) }\end{array}$ & $\begin{array}{l}\text { Key and } \\
\text { Benson, } 2005\end{array}$ & $\begin{array}{l}\text { Index derived from Landsat Tier } 1 \\
\text { imagery }\end{array}$ & 2.4 .4 \\
\hline
\end{tabular}

apes) over many generations (Olson and Dinerstein, 2001; Takemoto et al., 2015). To represent these regions, we split areas east and west of the Congo River, and north and south of Ubangi river. We further distinguish sub-montane and montane vegetation according to elevations above $1100 \mathrm{~m}$ and $1750 \mathrm{~m}$ respectively (Verhegghen et al., 2012). Finally, we identified an area of Marantaceae dominated forests in the Republic of Congo based on expert input. The final product was a map of 64 unique forest ecosystem classes for the year 2000 (see supplemental material for a list of all forest ecosystem types), which was updated to a second epoch of 2016 by removing all areas identified as tree cover loss by Hansen et al. (2013). The forest ecosystem maps for both epochs were used to create binary forest/non-forest masks for 2000 and 2016.

\subsubsection{Above ground biomass (AGB)}

Spatially-explicit AGB $(\mathrm{Mg} / \mathrm{ha})$ at the Congo Basin scale was sourced from the integrated pan-tropical dataset developed by Avitabile et al. (2016) at $1 \mathrm{~km}$ resolution. We further tested the index in the DRC using a finer scale national dataset calibrated by airborne LiDAR (Light Detection and Ranging; Section 2.4.1) and field data, extrapolated to the all DRC forests using wall-to-wall Landsat, ALOS PALSAR active radar and topography datasets as described in Xu et al. (2017).

\subsection{Developing a forest condition metric}

We estimated FC by combining forest fragmentation change and the relative loss in AGB for each transition between fragmentation classes. This process of anthropogenic deforestation encroaching on forest stands results in greater edges (Broadbent et al., 2008; Gascon et al., 2000), and the relative AGB (in the absence of real-time carbon 
monitoring) of each of these fragmentation classes allows us to assess an indicator of forest structure ranging from a maximum theoretical intact state to completely deforested. To achieve this we assigned the forest/ non-forest mask from the two time periods (2000 and 2016) into fragmentation classes using Morphological Spatial Pattern Analysis (MSPA) from the GUIDOS toolbox (Soille and Vogt, 2009; Vogt and Riitters, 2017). The edge distance has a significant impact on the resulting metric, and we use an edge distance of $300 \mathrm{~m}$, which we consider an appropriate distance of satellite measurable impact into intact tropical forests (Harper et al., 2005; Shapiro et al., 2016). We reclassed bridges and loops to inner and outer edges based on their location on the boundary of interior or exterior non-forest patches respectively. Thus, forest cover in each time period is assigned into one of four fragmentation classes: core, inner edge, outer edge and patch forest. We calculate the mean AGB in each fragmentation class of each ecosystem type.

We then assess transitions in fragmentation classes from 2000 to 2016 as a result of change in forest cover pattern, identified as areas that change from core forest to other fragmentation classes, identifying which forest pixels remain in the same class, versus transitions between different classes, which are assigned primary and secondary deforestation, primary and secondary degradation, as shown in Fig. 2. We discern two types of edges, inner perforations and outer edges bordering nonforest, as these have significantly different biomass (Shapiro et al., 2016), and have also been shown to be a result of different anthropogenic land uses (Molinario et al., 2020). Similar subsequent categories of core and edge forest according to canopy height have been described in Brazilian rainforests (Silva Junior et al., 2020).

The change in above-ground biomass between two time periods (2000 to 2016) was calculated from using a process analogous to the gain-loss method for carbon stock monitoring using the mean AGB of each fragmentation class of each forest ecosystem (Murdiyarso et al., 2008). Gains and losses in AGB are calculated according to differences between fragmentation/forest ecosystem strata means (Shapiro et al., 2016).

We compute FC as a continuous metric from 0 to 100, based on the percentage change in biomass between classes as a proportion of the maximum potential AGB, thereby integrating the temporal dynamics of a forest area that is an indication of not only present state (one snapshot: degraded or not) but the state in a trajectory from intact to deforested. This transition is determined according to the proportion of AGB remaining in comparison to the mean AGB of the core forest class (maximum intactness). Relative FC was then estimated on a continuous scale from fully intact (100) to completely lost (0), based on the proportional loss of biomass between fragmentation classes for two time periods.

FC of the second time period $\mathrm{j}$ for each forest ecosystem is calculated using the following Eq. (1)

$C_{t j}=100 *(\mathrm{AGBtj} / \mathrm{AGBti})$

where $\mathrm{c}$ is the condition of that specific forest ecosystem fragmentation strata at any time $t$ (denoted by $\mathrm{tj}$ ), based on the AGB of the previous and current fragmentation category.

To differentiate an ecosystem that has changed to a new state versus one that is stable, we assess overall Forest Condition (FC) using Eq. (2):

$F C_{t j}=C_{t j}-\left(\frac{A G B_{t j}}{A G B_{t i}}\right) * C_{t j}$

\subsection{Testing the FC metric in $D R C$}

\subsubsection{Forest canopy height}

Forest canopy height was estimated using the airborne LiDAR dataset collected in 2014 and 2015 throughout the DRC following a systematic random sampling pattern, as described by the VCS VT0005 methodology (Tittmann et al., 2015; Xu et al., 2017). In total, 216 random plots of 2000 ha each were distributed over a $1^{\circ} \times 1^{\circ}$ grid laid over the national primary dense forest cover dataset for DRC (Potapov et al., 2012). LiDAR data were collected with a mean point density of $2 / \mathrm{m}^{2}$ from which digital surface models and mean canopy height were derived at $2 \mathrm{~m}$ meter resolution (Xu et al., 2017). All canopy heights above $3 \mathrm{~m}$ (national forest definition) were used to create a detailed forest cover map for these LiDAR sampling areas, and further used to develop the variables described in the following two sections.

\subsubsection{Forest gap area}

Forest gap area was estimated using the difference between the LIDAR canopy height and a maximum estimated within a 50-cell

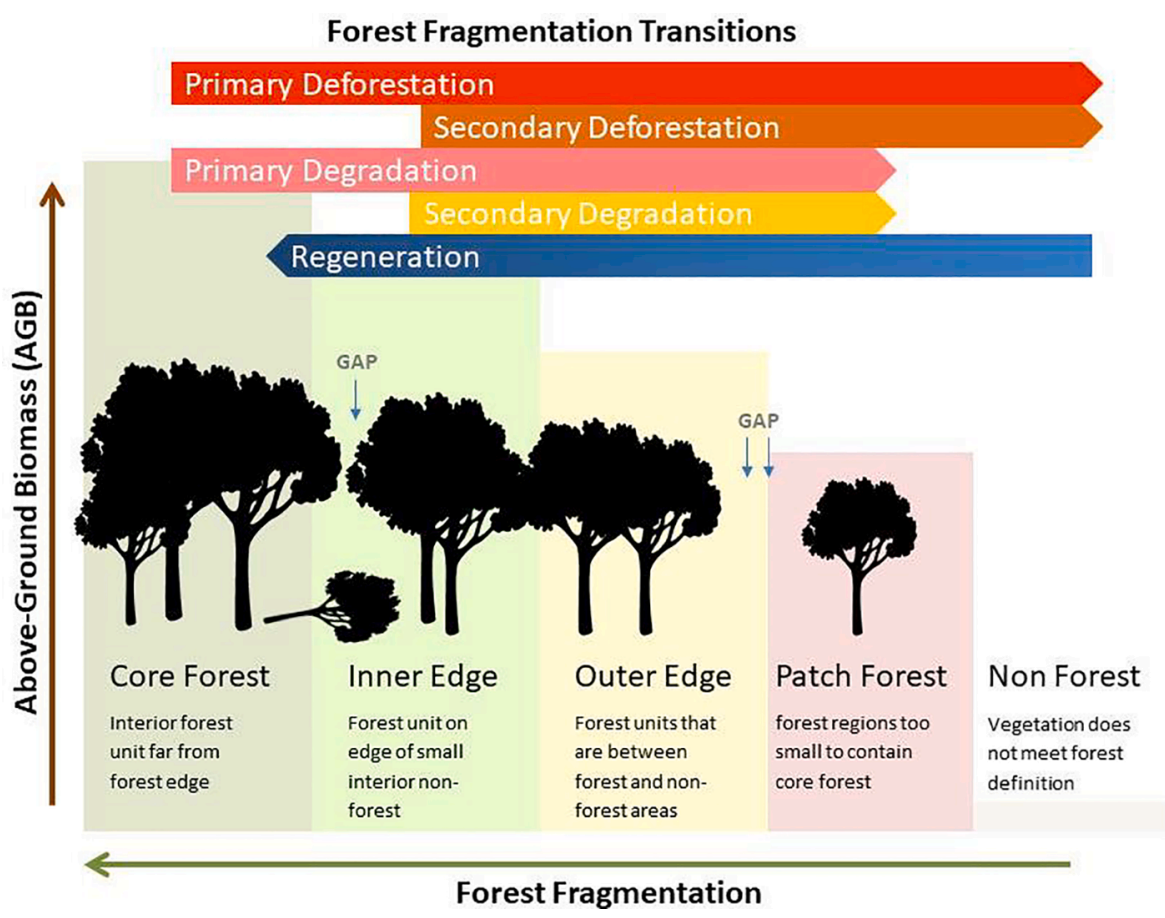

Fig. 2. Theoretical concept of forest condition (FC) as a combination of AGB, deforestation and degradation transitions via fragmentation. A forest/non-forest map is classified into 5 fragmentation types (core, inner edge, outer edge, patch forest) which have decreasing levels of above-ground biomass (AGB) respectively and a greater presence of canopy gaps. The transitions between classes from one time period to the next are described in the top of the figure with an arrow that has a beginning point and an end, e.g. a change in core forest to outer edge is primary degradation. An inner edge forest that becomes non-forest is secondary deforestation. Stable forest types are primary forest (core forest with no change) and secondary forest (inner and outer edges, patch forests with no change). 
window (or 1 ha, following Betts et al., 2019). Gaps were identified using a threshold of $21 \mathrm{~m}$ less than the canopy maximum, which located all gap areas within continuous forest, verified by the very high resolution $(10 \mathrm{~cm})$ airborne imagery collected by the same airborne data collection campaign. The gap area was then summed for each hectare in the LiDAR footprints and sampled using the random sample of 100 points per LiDAR plot.

\subsubsection{Fractional cover}

Forest fractional cover was estimated from the $2 \mathrm{~m}$ LiDAR-derived forest canopy height (Section 2.4.1) by summing the total number of cells in a $50 \times 50$ window and calculating the proportion of 2500 cells covered by forest to produce $\%$ forest cover at the 1 ha scale.

\subsubsection{Normalized burn ratio (NBR)}

We used the normalized burn ratio index (NBR; (Key and Benson, 2005) as a direct remote sensing indicator of canopy disturbance associated with encroachment and illegal logging (Langner et al., 2018). We calculated NBR from Landsat surface reflectance imagery from the USGS Tier 1 collection from 1984 to 2016 processed in Google Earth Engine (Gorelick et al., 2017). All available Landsat data since 1984 were compiled, filtered by cloud cover $(<90 \%)$, poor quality pixels were masked according to pixel quality (Foga et al., 2017); and the image collected was sorted by acquisition date. We use a cumulative anomaly analysis to assess NBR in a monitoring period (2000-2016) compared to a baseline historical period (all previously available imagery from 1984 to 1999), where all Landsat images are sorted in time, and the differences with the mean are sequentially summed and divided by the number of available images. From 2000 onward, coinciding with the first year of forest condition transition assessment, the difference between calculated NBR for each cloud-free pixel and the historical mean was calculated, summed, and normalized by the number of non-null observations as in Lagomasino et al. (2019). An area with a time period of high positive anomalies (higher NBR than historical mean) followed by subsequently larger negative anomalies, will have an overall high negative accumulated anomaly.

We assessed the performance of FC and the theoretical framework in several ways for the DRC, for which we have detailed validation data Table 1). We correlated FC with fractional forest cover and canopy gap area, along with the estimate of biomass lost and the NBR cumulative anomalies. This was done using a random sample of 50 points distributed inside the fragmentation classes inside each LiDAR plot ( $\mathrm{n}=$ 10,800) from (Xu et al., 2017) in order to assess forest structure variables of fractional cover and gap area, biomass lost and anomaly using a Pearson correlation matrix executed in $\mathrm{R}$ software (version 3.5.1). Negative cumulative anomalies of NBR (Section 2.4.4) were evaluated within each degradation class using analysis of variance (ANOVA) of the same random sample of points as above. These were further evaluated using the Tukey honest significant difference pairwise test (Bland and Altman, 1995) to determine significant differences between paired fragmentation transition classes.

\subsection{IUCN Red List of ecosystems assessment}

To estimate the risk of ecosystem collapse for each of the forest ecosystem types, we applied the IUCN Red List of Ecosystem criteria A2b, B1 and B2 and D (Bland et al., 2015) summarized in Table 2. The Red List of Ecosystems employ a rule-based protocol that utilises information on spatial change, range size, and biotic and abiotic variables for each ecosystem to identify ecosystems at risk of ecosystem collapse.

Criterion A2b was applied to assess the reduction in geographic extent of each ecosystem over a 50 -year period. We used the adjusted proportional rate of decline based on the extent data for two time periods, 2000 and 2016 (See Section 2.1.1). To assess the range size

Table 2

Summary of relevant IUCN Red List for ecosystems criteria applied in this assessment.

\begin{tabular}{|c|c|c|c|c|c|}
\hline Criterion & Description & \multicolumn{2}{|c|}{ Red List category } & \multicolumn{2}{|l|}{ Thresholds } \\
\hline \multirow[t]{3}{*}{$A 2 b$} & \multirow{3}{*}{$\begin{array}{l}\text { Reduction in geographic distribution in } \\
\text { any } 50 \text {-year period including the past, } \\
\text { present and future: }\end{array}$} & \multicolumn{2}{|c|}{ CR } & \multicolumn{2}{|l|}{$\geq 80 \%$} \\
\hline & & \multicolumn{2}{|l|}{ EN } & \multicolumn{2}{|l|}{$\geq 50 \%$} \\
\hline & & \multicolumn{2}{|l|}{ VU } & \multicolumn{2}{|l|}{$\geq 30 \%$} \\
\hline \multirow[t]{3}{*}{ B1 } & \multirow{3}{*}{$\begin{array}{l}\text { Extent of a minimum convex polygon } \\
\text { enclosing all occurrences (extent of } \\
\text { occurrence, EOO) is no larger than: }\end{array}$} & \multicolumn{2}{|l|}{ CR } & $2000 \mathrm{~km}^{2}$ & \multirow{3}{*}{$\begin{array}{l}+ \\
\text { subcriteria } \\
\text { (see Bland } \\
\text { et al. } \\
\text { 2015) }\end{array}$} \\
\hline & & \multicolumn{2}{|l|}{ EN } & $\begin{array}{l}20,000 \\
\mathrm{~km}^{2}\end{array}$ & \\
\hline & & \multicolumn{2}{|l|}{ VU } & $\begin{array}{l}50,000 \\
\mathrm{~km}^{2}\end{array}$ & \\
\hline \multirow[t]{3}{*}{ B2 } & \multirow{3}{*}{$\begin{array}{l}\text { The number of } 10 \times 10 \mathrm{~km} \text { grid cells } \\
\text { occupied (are of occupancy, AOO) is no } \\
\text { more than: } \\
1 \% \text { rule: grid cells with patches of the } \\
\text { ecosystem type accounting for less } \\
\text { than } 1 \% \text { of grid cell area are excluded }\end{array}$} & \multicolumn{2}{|l|}{$\mathrm{CR}$} & 2 & \multirow{3}{*}{$\begin{array}{l}\text { + sub- } \\
\text { criteria }\end{array}$} \\
\hline & & EN & & 20 & \\
\hline & & \multicolumn{2}{|l|}{ VU } & 50 & \\
\hline \multirow[t]{5}{*}{$\mathrm{D} 2 \mathrm{a}$} & \multirow{5}{*}{$\begin{array}{l}\text { Disruption of biotic processes or } \\
\text { interactions over any } 50 \text {-year period, } \\
\text { based on a change affecting a fraction } \\
\text { of the extent of the ecosystem with an } \\
\text { estimate of relative severity }\end{array}$} & & \multicolumn{3}{|c|}{ Relative severity (\%) } \\
\hline & & $\begin{array}{l}\text { Extent } \\
(\%)\end{array}$ & $\geq 80$ & $\geq 50$ & $\geq 30$ \\
\hline & & $\geq 80$ & CR & EN & VU \\
\hline & & $\geq 50$ & EN & VU & \\
\hline & & $\geq 30$ & VU & & \\
\hline \multirow[t]{5}{*}{ D3 } & \multirow{5}{*}{$\begin{array}{l}\text { Disruption of biotic processes or } \\
\text { interactions since } 1750 \text {, based on a } \\
\text { change affecting a fraction of the } \\
\text { extent of the ecosystem with an } \\
\text { estimate of relative severity }\end{array}$} & $\begin{array}{l}\text { Extent } \\
\text { (\%) }\end{array}$ & \multicolumn{3}{|c|}{ Relative severity (\%) } \\
\hline & & & $\geq 80$ & $\geq 70$ & $\geq 50$ \\
\hline & & $\geq 90$ & CR & EN & VU \\
\hline & & $\geq 70$ & EN & VU & \\
\hline & & $\geq 50$ & VU & & \\
\hline
\end{tabular}


criterion $\mathrm{B}$, we computed extent of occurrence as a minimum convex polygon encompassing all occurrences of each ecosystem (criterion B1) and area of occupancy using the 1\% occupancy rule (criterion B2) and appropriate sub-criteria as described in (Bland et al., 2015).

Criterion D focusses on the disruption of biotic processes (Bland et al., 2017), for which we applied the area of primary degradation (see Fig. 2) as the extent of the disruption, and the mean forest condition to indicate severity. Forest edges are known for their detrimental effects on ecosystems services and vertebrate habitats (Pfeifer et al., 2017), thus, making a fragmentation approach relevant for conservation prioritization applications. Instead of the recommended 1750, we use the year 1850 as the historical reference because prior to then forests in the Congo Basin were considered largely free of human disturbances and industrial development (Morin-Rivat et al., 2017). Both sub-criteria D2 and D3 were evaluated to determine the validity of these assumptions.

The change in FC over the 16 year study period was used as an indicator of biotic disruption, as reduced AGB affects the delivery of ecosystem services such as climate change mitigation over time, (Heymell et al., 2011; Pettorelli et al., 2018; Shvidenko et al., 2005). The change in amount of core forest versus edge classes determined the extent of the ecosystem affected by fragmentation, edge effects (Haddad et al., 2015) for criterion D3, while the changes in mean forest condition per ecosystem were used to assess relative severity of degradation for the severity.

FC, by definition assumes that at some initial point in time, all forests were intact ecosystems with $100 \%$ condition, thus providing the information needed to assess two of the sub-criteria D2a and D3. For D2a, we presume the rates of change of core versus edges determine the fraction of the extent of the ecosystem affected since 2000; and these are projected to 2050 using the proportional annual rate of decline (PRD; Rodríguez et al., 2015). For D3, we assessed the proportional rates of decline over the actual annual rates of decline (ARD) in mean FC by ecosystem which were modelled using the changes from 1850 to 2016, with the assumption that in 1850, all forest ecosystems were core intact forest with maximum potential biomass (Fig. 3).

The final ecosystem status was assigned as the highest assessment outcome between all three criteria evaluated, A, B and D (See Fig. 4).

\section{Results}

\subsection{Condition of Congo Basin ecosystems}

Our forest ecosystem map shows the Congo Basin forests cover more

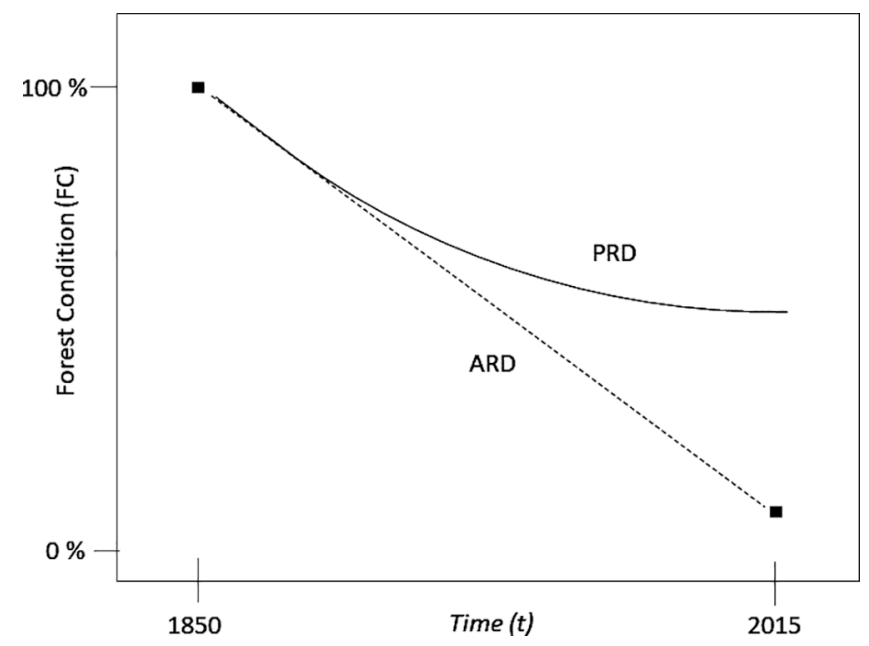

Fig. 3. The correlation between forest condition estimated in 2015, and the assumed $100 \%$ condition in 1850, can be calculated using either annual rates of decline (ARD) or proportional rate of decline (PRD, adapted from (Rodríguez et al., 2015). than 210 million ha in 2000 and are predominantly lowland, equatorial semi-deciduous forests with a significant swamp forest ecosystem in the central region covering more than 29 million hectares (See Fig. 5).

The condition of these 64 forest ecosystems vary widely across the region. Overall we estimate that in $2000,78 \%$ of all forest area was intact, core forest, decreasing to $67 \%$ in 2016 (intact forests shown in blue, Fig. 6) where more than 23 million hectares of core forest transitioned to edge classes. For broad forest types, open forests and mangroves have the lowest mean FC, while swamp forests and the mixed evergreen and semi-deciduous rainforests have the highest mean FC (Table 3). The localized Marantaceae forests have the highest mean condition. High condition forest $(>80)$ is generally present in the dense forest ecosystems in Gabon, which have the highest mean forest condition, followed by Republic of Congo (Table 3). Large areas of lower condition $(<50)$ are present in eastern DRC, along the Congo river and in the southwest corner of DRC, and south central Cameroon, while fragmented, low condition forests are predominant in the Central African Republic (See Table 4).

\subsection{Validating $F C$ in the $D R C$}

Using the detailed LiDAR dataset for random sample plots in the DRC, $(\mathrm{n}=21,600)$ FC was shown to be significantly, yet weakly correlated with fractional cover, gaps, biomass loss and NBR anomalies, with the greatest negative correlation with gaps and biomass loss (Fig. 7). The NBR anomalies also show the highest positive correlation with fractional cover, where greater negative anomalies are correlated with lower fractional cover.

When assessing gap area by transition type, gap area decreases significantly for stable classes (primary and secondary forest), with the highest gap area observed in areas which were identified as primary deforestation (Fig. 8). Gap area was significantly different deforestation and degradation, but not statistically different to discern changes in primary or secondary types of forest.

Mean cumulative negative anomalies were observed to be lowest overall in areas defined as primary or secondary deforestation, and less in degraded areas, and closest to zero in stable forest types with no change. All paired combinations were significantly different, with the exception of primary and secondary deforestation (See Fig. 9).

\subsection{Red list of ecosystems assessment}

Our assessment of the Red List of Ecosystem criteria indicates that 4 ecosystems are critically endangered, 15 endangered, and 14 vulnerable (Table 5; Fig. 10). The remaining did not meet any of the category thresholds and are therefore listed as least concern. The full table of ecosystems and criteria are presented in the supplementary material, showing that criterion $\mathrm{D}$, which was based on $\mathrm{FC}$ was also triggered when criterions A and B were, however, additional ecosystems met criterion D alone.

The four critically endangered ecosystems are located in DRC, notably in and around the Virunga and Kahuzi-Biega National Parks (Fig. 10) are shown to have low condition, and experienced significant biomass loss and forest cover loss. DRC also hosts the majority of the endangered ecosystems, along the Congo River and in the west near Angola, along with the northern open forests. Central African Republic is dominated by fragmented, endangered open forests, and the Republic of Congo has large areas of vulnerable ecosystems. In the central cuvette, swamp forests are vulnerable in DRC and Republic of Congo. Several dense, evergreen and semi-deciduous forests in the northeast and northwest regions fall in the endangered categories, while three types of swamp forest ecosystems fall in the vulnerable category.

Of the 33 ecosystems qualified as above least concern, 21 qualified for ranking in a category above Least Concern for criterion A or B as well as $\mathrm{D}$, indicating general agreement between the criteria (Table 6). An additional 12 ecosystems were assigned a threat ranking according to 


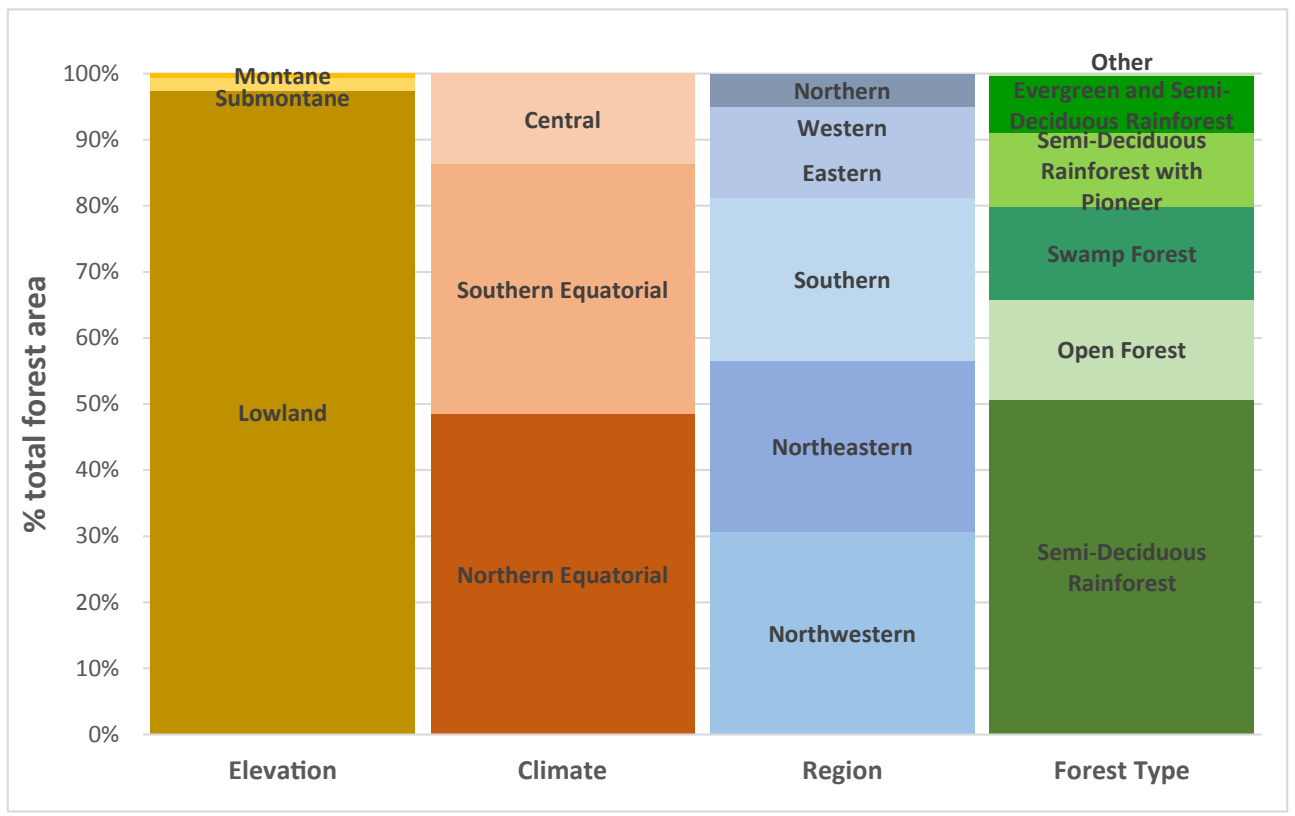

Fig. 4. Congo Basin forest composition by region, forest type, elevation and climate. (Other forest types include mangrove and Marantaceae).
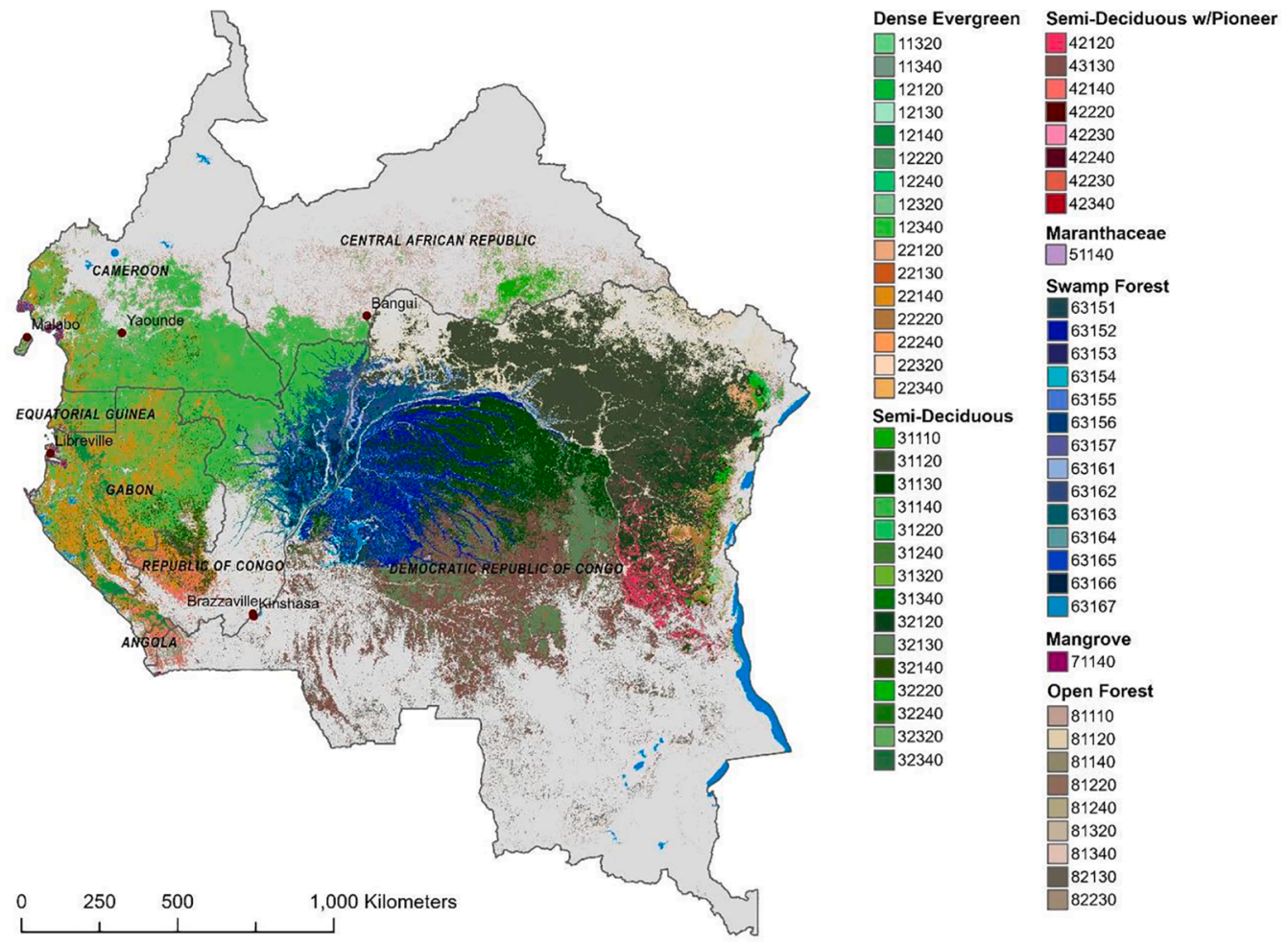

Fig. 5. Distribution of forest ecosystem types of the Congo Basin. The codes indicate the hierarchical classification scheme and are explained in the supplemental material.

criterion D alone, meaning they did not undergo a significant change in extent, but rather extensive and significantly decreasing condition. These means that $11.6 \%$ of present forest ecosystems would have been missed as being categorized without applying FC. These ecosystems included several categories of open forests, which were assigned the higher threat class of endangered due to the extent and severity thresholds for criterion D, while all four critically endangered ecosystems were assigned a higher risk class due to criterion D than A or D. In contrast, no ecosystems were assigned a threat status according to A or B alone, which is expected as reduced area is associated with a reduced core area.

The trajectory of FC over time assessed differs for each ecosystem and Red List category. The critically endangered ecosystems are shown to decrease more rapidly after 2012, except for the evergreen/semideciduous ecosystem (upper most red line) which has a slower decline in FC over time, and its threat status mostly due to limited extent. The lowest lines represent the open forests which overall lower condition compared to other ecosystem types, as they are greatly fragmented and 


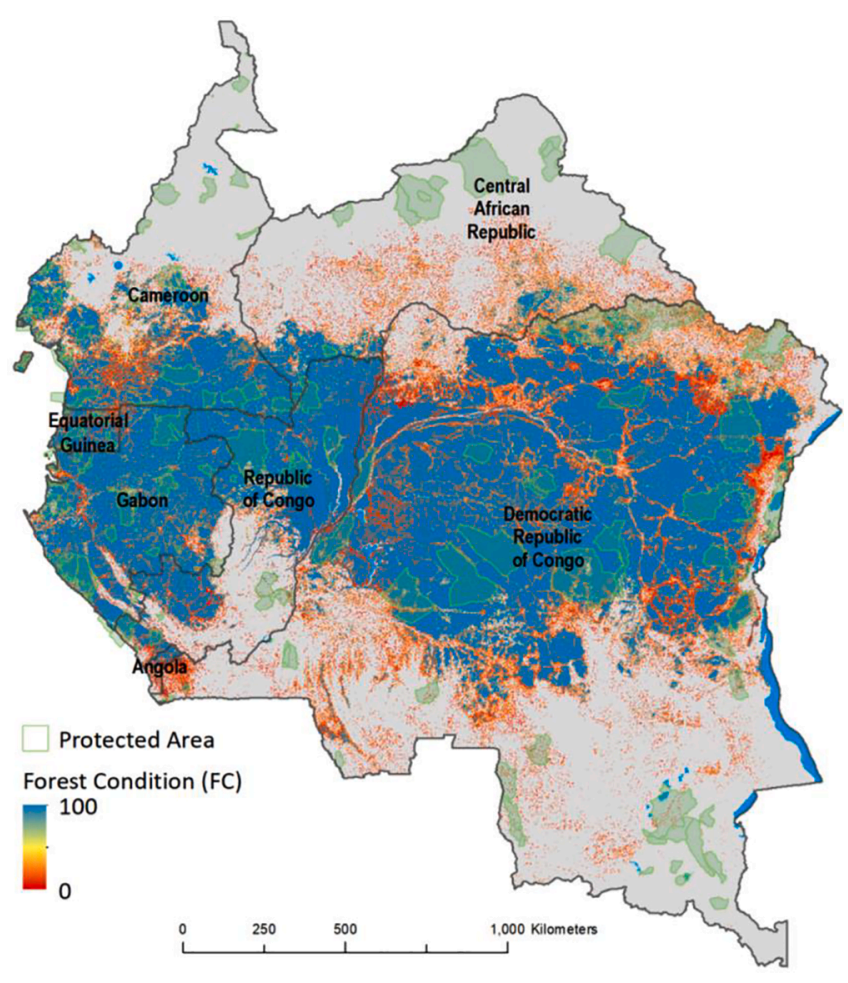

Fig. 6. Forest Condition for Congo Basin forests (2015). Protected areas data from (Pélissier et al., 2019) and WRI Forest Atlases (World Resources Institute, 2019).

Table 3

Mean FC by broad forest type.

\begin{tabular}{llll}
\hline Broad forest type & Total Area (ha) & Mean FC & Std. dev. \\
\hline Dense evergreen rainforest & $4,457,859$ & 82.13 & 32.24 \\
Evergreen and semi-deciduous & $18,177,916$ & 89.92 & 25.99 \\
$\quad$ Rainforest & & & \\
Semi-deciduous rainforest & $104,332,094$ & 85.24 & 30.38 \\
Semi-deciduous rainforest with pioneer & $22,453,096$ & 75.14 & 38.05 \\
Marantaceae & 267,717 & 91.71 & 20.81 \\
Swamp forest & $28,928,944$ & 85.88 & 32.02 \\
Mangrove & 402,780 & 64.71 & 40.51 \\
Open forest & $31,239,177$ & 18.93 & 15.22 \\
\hline
\end{tabular}

Table 4

Mean FC by congo basin country.

\begin{tabular}{lllll}
\hline Country & $\begin{array}{l}\text { Total Area } \\
\text { (ha) }\end{array}$ & $\begin{array}{l}\text { Forest area 2015 } \\
\text { (ha) }\end{array}$ & $\begin{array}{l}\text { Mean } \\
\text { FC }\end{array}$ & $\begin{array}{l}\text { Std. } \\
\text { dev. }\end{array}$ \\
\hline Cameroon & $47,177,546$ & $21,686,790$ & 75.21 & 36.41 \\
$\quad \begin{array}{l}\text { Central African } \\
\quad \text { Republic }\end{array}$ & $62,889,075$ & $11,385,949$ & 45.47 & 39.32 \\
$\quad \begin{array}{ll}\text { Republic of Congo } \\
\text { Equatorial Guinea }\end{array}$ & $34,220,955$ & $23,701,530$ & 84.91 & 31.97 \\
$\quad \begin{array}{l}\text { Gabon } \\
\text { Democratic Republic }\end{array}$ & $2,701,407$ & $2,594,197$ & 77.27 & 35.99 \\
$\quad$ of Congo & $234,751,788$ & $126,437,088$ & 73.25 & 38.58 \\
Angola & 712,269 & 514,097 & & \\
\hline
\end{tabular}

as a result have a much lower than the maximum potential AGB.

\section{Discussion}

We identified 64 unique forest ecosystems that provide a fundamental basis for representative and comprehensive conservation planning in the Congo Basin region. Although forest cover is still quite extensive, the impacts of forest degradation and fragmentation are high (33\% of overall forest area), reducing the capacity of forests to support biodiversity and ecosystem services. We found notable areas of degradation in eastern mountains of DRC and southern, northern peripheries of semi-deciduous forests stands; the open forests of Central African Republic and southern Cameroon. Our forest condition index assesses the extent of degradation, which can be used within the Red List for Ecosystems risk classification framework. Through our analysis we have developed functional tools to support the RLE by defining ecosystems with reduced extent and significantly reduced condition. The application of FC to evaluate potential ecosystem collapse has provided additional information than extent or size alone (criterions A and B) and 18\% of forest area would not have been identified as threatened if it were not applied.

We characterize FC as a combination of biomass lost and fragmentation over time to produce a metric on a continuous scale from 0 to $100 \%$. In contrast with indicators that provide a single snapshot in time, binary assessments of intact versus not (Potapov et al., 2008; Tyukavina et al., 2016)or classifications of forest intactness (Molinario et al., 2015), FC has the unique element of incorporating a temporal dimension of biomass loss to produce a relative index of degradation on a continuous scale. This output allows an end user to decide their own classification or thresholding approach which could be specific to their geography. The integration of temporal information is an important requirement for accurately identifying the forest degradation process, and differentiating a regenerating secondary forest from one which is stable, or from one which may have previously been intact (Thompson et al., 2013). The overall approach to developing this metric lies in a specific definition of forest degradation based on AGB, related to the climate regulating services of intact forest ecosystems (Pan et al., 2011). Therefore, the assessment of FC over time provides an important metric for monitoring forests capacity to either sequester or emit forest carbon over time, but is not limited to such use as it can be used to prioritize restoration efforts.

FC was positively correlated with forest canopy fractional cover, biomass lost over time, and negatively associated gap area at 1 ha scale, validating the theoretical model of subsequent states of degradation presented in Fig. 2. The assessment of forest transitions (primary and secondary deforestation and degradation) gap area and cumulative anomalies of direct assessments of long-term changes in NBR provide more context in describing the successive forest states which lead to deforestation. The incremental significant differences point to an indicator which can accurately discern deforestation from degradation, and the combination of temporal data with biomass allows for more information than any of these variables alone. FC and transitions together provide an informative stratification for cost-effective conservation planning, monitoring and climate change interventions, as direct measures of forest gaps, fractional cover or direct remote sensing metrics alone do not inform the prior status of a forest ecosystem. High resolution forest structure and gap area require significant investments into very high resolution airborne or drone data which are not always feasible. While fractional cover remains highly correlated with the other validation variables, fractional tree cover from satellite cannot adequately discern different forest heights or high or low biomass ecosystems. Additionally, a forest with a continuous canopy will have the same fractional cover regardless of its biomass, structure, making it inadequate to independently assess relative degradation state.

The Landsat observation frequency is not always ideal for wall-towall degradation detection, particularly before Sentinel-2, and higher resolution sensors such as Planet data have cost barriers and are less spectrally consistent than lower resolution sensors. While the methodology we developed for measuring forest degradation is an indirect method, incurring greater assumptions and over-simplification of processes, they can be adapted and flexible to rapid monitoring assessments. Indirect methods are generally simpler, but can provide the necessary information for conservation planning or targeting of interventions (Grantham et al., 2020a, 2020b; Pelletier et al., 2013). We 


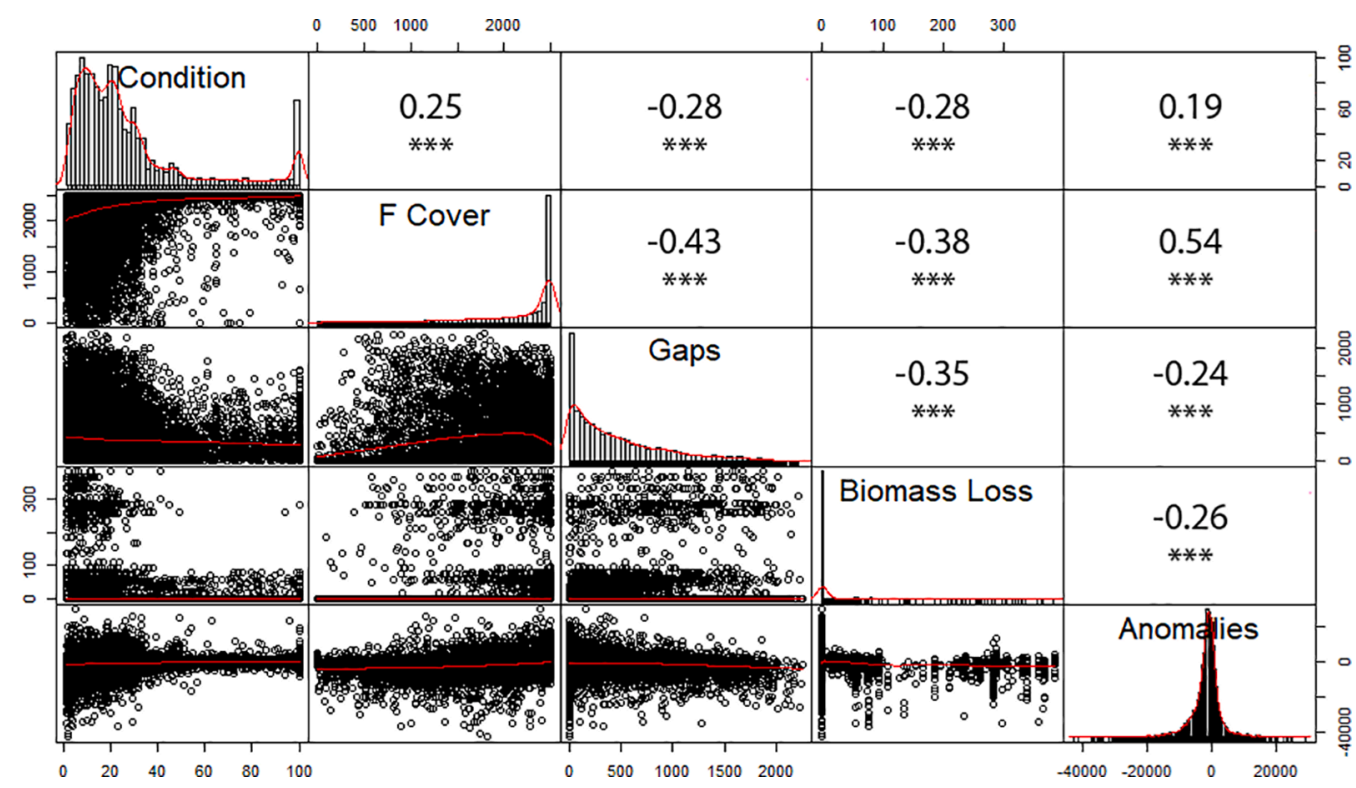

Fig. 7. Correlation matrix of sampled variables including ecosystem condition, fractional cover at 1 ha (F Cover, Section 2.4.3), Biomass loss ( $\mathrm{Mg} / \mathrm{ha}$, Section 2.2.2) and the NBR Anomalies Section 2.2.6. The distribution of each variable is shown on the diagonal, bivariate scatter plots on the lower left, and the correlation coefficient shown as a value. Significance levels are denoted by red stars (3 stars: $p<0.001 ; 1$ star: $p<$ 0.05). (For interpretation of the references to color in this figure legend, the reader is referred to the web version of this article.)
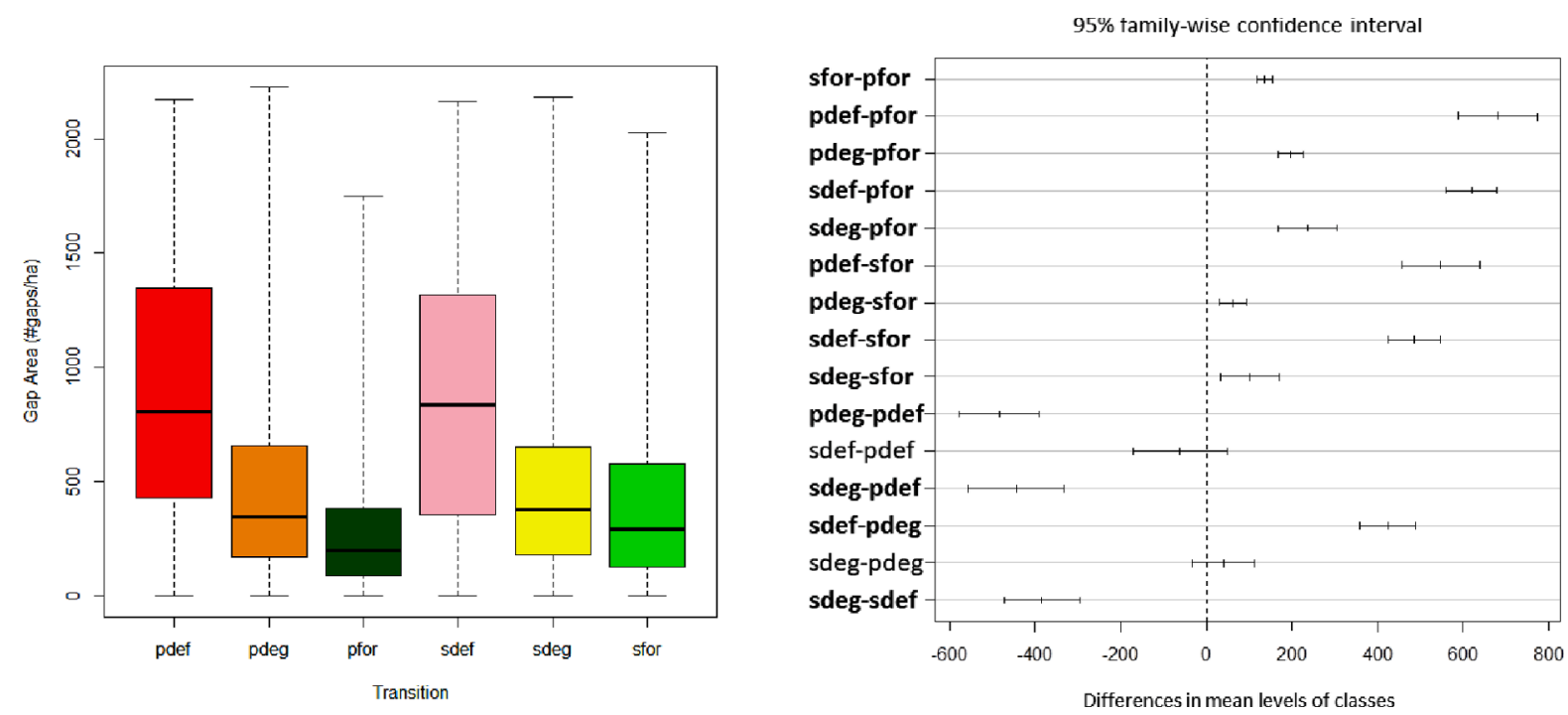

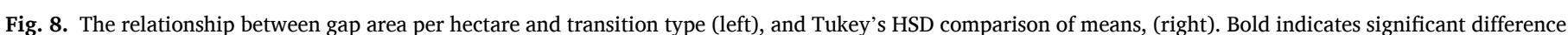

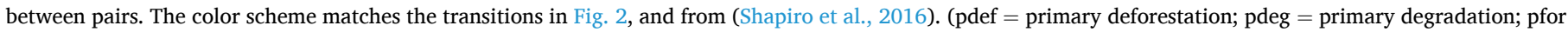
= primary forest; sdef = secondary deforestation; sdeg = secondary degradation; sfor = secondary forest).

have demonstrated that the integration of temporal information can differentiate primary from secondary deforestation where a direct spectral measure or estimation of fractional cover cannot.

Our validation shows that FC is correlated with decreasing gap area, increasing canopy height and cumulative NBR anomalies, supporting the theoretical framework and transition definitions proposed in Fig. 1. Tukey HSD pairings of differences in mean canopy gap, and anomalies are significantly different, with the exception of primary and secondary deforestation, which were not significant in the paired variable tests. This is not entirely unexpected, as a deforested ecosystems are similar whether it was previously intact or already degraded. For this reason, FC provides important contextual information, to differentiate the differences in subsequent degradation transitions from stable secondary or degraded forests and provides a suitable indirect method to meet most monitoring needs.

For direct remote sensing approaches to degradation, indicators directly related to canopy changes are necessary (Mitchell et al., 2017). To validate our approach, we chose NBR as a suitable index to detect pixel components of bare soil within tropical forests, an indicator of canopy closure and does not suffer from the saturation effects of NDVI, or the calibration required for spectral mixing approaches (Langner et al., 2018). The presence of bamboo understories or deciduous species in the forest community, however, could falsely detect canopy openings, however a long term cumulative anomaly approach, in which increases in NBR cancel out decreases should effectively remove seasonality and discern long term changes. Despite a suitable direct indicator, cumulative NBR anomalies alone cannot discern degradation events which may be followed by quick regeneration, nor does it differentiate between different types of forest dynamics. An assessment of trends, for example using LandTrendr (Kennedy et al., 2010), might be required to investigate various transitions, but still aren't designed to assess the relative changes occurring in primary or secondary forest types, or elements 

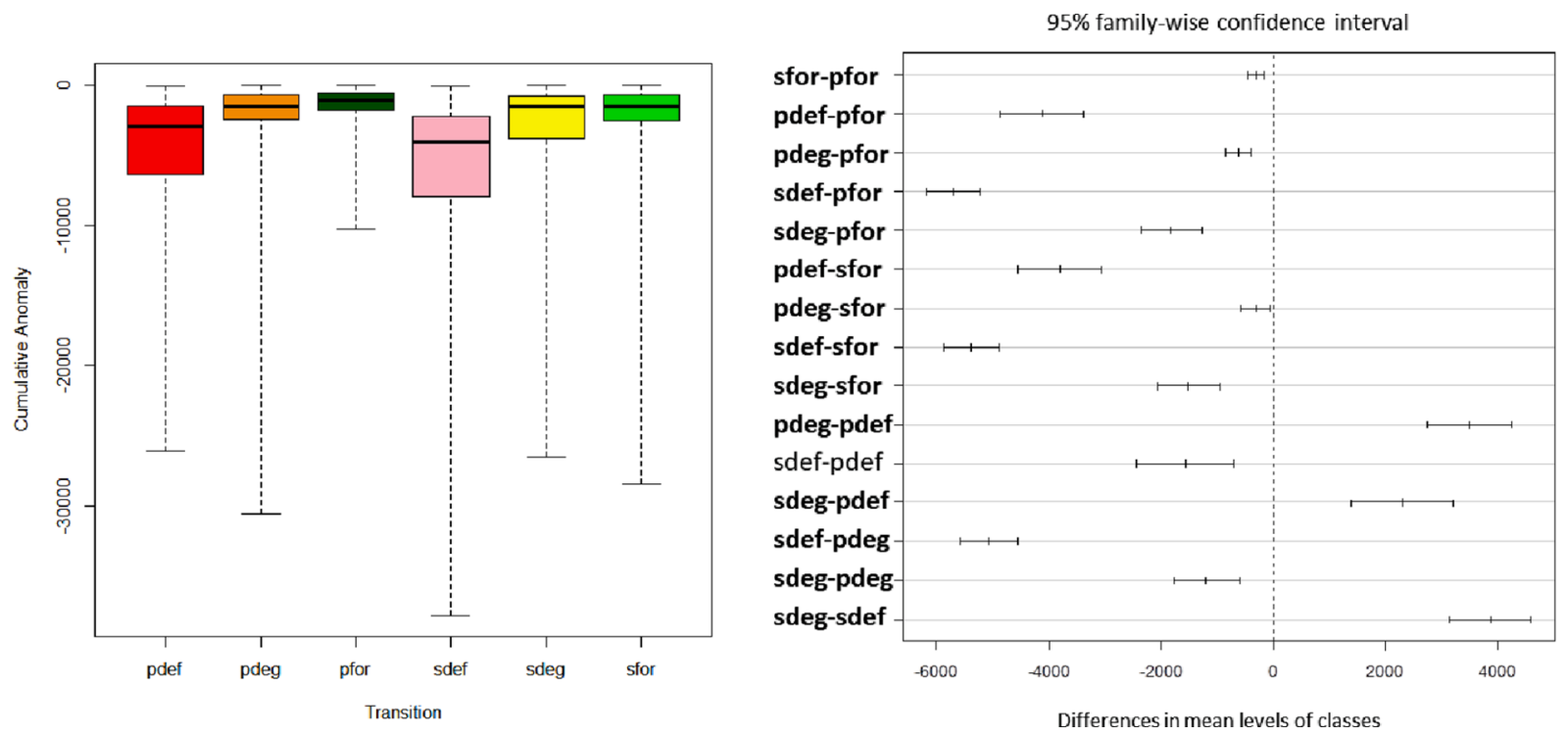

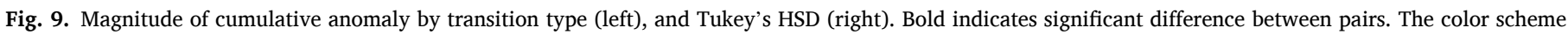

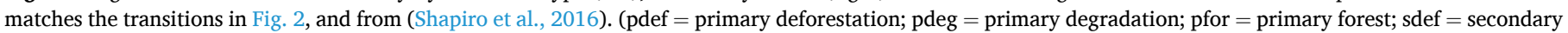
deforestation; sdeg = secondary degradation; sfor = secondary forest).

correlated to AGB, as these require consistent long term cloud-free time series data and calibration information that remain sensitive to short term dynamics.

FC can also support conservation prioritization and planning in many ways. Our approach can integrate a flexible number of time steps (minimum of two to incorporate the temporal dimension) but can be calculated over subsequent annual time series (Fig. 11) which can support adaptive monitoring or alert approaches, for example, identifying when an ecosystem FC dips below a certain threshold. This method has also supported the prioritization of forest areas for high conservation value assessments (Grantham et al., 2020a, 2020b) or via the ecosystem Red List addressed in further detail in the next section. We observed varying estimates of FC for individual ecosystems, where areas with lower condition may be prioritized for restoration activities, while those with high overall condition could be managed for conservation and carbon stock maintenance.

In comparison with binary indices such as Intact Forest Landscapes (Potapov et al., 2008), hinterland forests (Tyukavina et al., 2016), methods identifying core and edge (Haddad et al., 2015; Riitters et al., 2016), or approaches classifying post-deforestation changes and land use (Molinario et al., 2020, 2015), FC provides a continuous index which has parameters which can be adjusted and applied according to specific needs or geographies. This is important for adapting the method to different context or forest types - although we do note that our metric might be biased towards continuous forest types, for example dense forest stands, as opposed to naturally open forests which are patchy in nature.

Our results are supported by analyses such as Molinario et al. (2020) who have defined different land cover trajectories and impacts for different edge types (inner versus outer). In particular in the Congo basin, FC identified many forests which happen to fall outside the IFL definition yet are the locations of essential corridors, valuable species habitats, or are identified as Key Biodiversity Areas (KBAs) (Birdlife International, 2018; IUCN, 2016a, 2016b). In addition, we provide a continuous metric integrating the temporal history supporting conservation prioritization and methods to rank areas by FC for different interventions - such as active restoration or mitigation activities to promote regeneration (Grantham et al., 2020).

\subsection{Application to IUCN Red List of ecosystems}

The application of FC for Criterion D of the IUCN Red List enabled us to assess the disruption of biotic processes over a large region, assessing both spatial extent of impact and the severity, which could be otherwise difficult to measure or estimate, for example biotic processes related to the loss of species richness, or changes in trophic diversity (see supplementary material of (Bland et al., 2015). We found that we would have under-estimated ecosystem risk by assigning the Red List category based only on the geographic extent and area of occupancy by applying criterion A and B only. The additional element of FC is necessary to assess ecosystem status independent of spatial extent. As our analysis has shown, 12 of the 64 ecosystems, representing more than $11 \%$ of total forest area in 2015 did not meet the risk criteria for A or B, but were triggered by criterion $\mathrm{D}$, while no ecosystems were classified at risk with only A or B. This was observed in all open forest categories in dryland ecosystems which despite their very fragmented state can still potentially harbour high AGB (Bastin et al., 2017). This high potential AGB in a very fragmented forests results in low FC and triggers extent and

Table 5

Redlist of Ecosystem summary for 64 Congo Basin Forest Ecosystems.

\begin{tabular}{|c|c|c|c|}
\hline Final Status & $\begin{array}{c}\text { Number of } \\
\text { ecosystems }\end{array}$ & Total Area (ha) & $\begin{array}{c}\text { \% of Congo Basin } \\
\text { Forest Area }\end{array}$ \\
\hline CR & 4 & 311,832 & 0.15 \\
\hline EN & 15 & $32,756,664$ & 15.25 \\
\hline VU & 14 & $14,042,047$ & 6.54 \\
\hline LC & 31 & $167,636,697$ & 78.06 \\
\hline Total & $\mathbf{6 4}$ & $\mathbf{2 1 4 , 7 4 7 , 2 4 0}$ & 100.00 \\
\hline
\end{tabular}




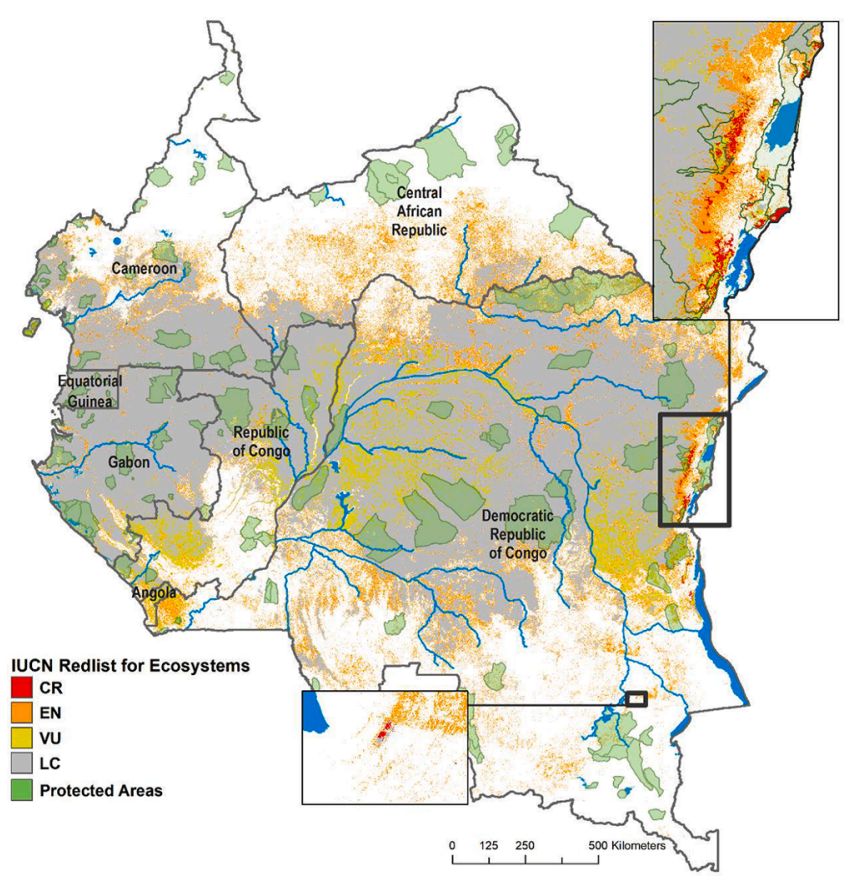

Fig. 10. IUCN Red List assessment for Congo Basin forest ecosystems. (For interpretation of the references to color in this figure legend, the reader is referred to the web version of this article.)

severity of criterion $\mathrm{D}$, while their large geographic distribution do not trigger criterion A or B. This shows that A and B do not adequately integrate fragmentation and pattern to assess ecosystems. It is also possible that these naturally fragmented forests are under-estimated by our metric focused on connectivity, meriting further attention. We do ultimately demonstrate that criterion D captures the ranking of several criteria and is an effective indicator for the ecosystem risk assessment, in both extent (calculated as \% core forest) and severity (measured by mean confition), as opposed to A and B which are focused primarily on extent. As ecosystem functioning, notably species biodiversity greatly affected by fragmentation (Haddad et al., 2015), it is logical and necessary to include spatial pattern metrics in an ecosystem risk assessment designed for conservation. The FC estimate directly addresses the concept of the endpoint $(\mathrm{FC}=0)$ of ecosystem decline, supporting the scientific underpinning of the ecosystem red list process (Keith et al., 2013) and can also be applied to other ecosystem prioritization efforts for conservation. Finally, this assessment has shown that that the principal driver of ecosystem collapse in Congolese forest systems are related to fragmentation and degradation, and while deforestation overall may remain low, there are significant pressures that can affect forest health and associated biodiversity (Grantham et al., 2020a, 2020b).

The availability of temporal data and trends over annual time steps enables a forward and backward modelling to fit the criteria requirements of estimating changes in FC over 50 years past or future predictions. Most importantly, the method has enabled the identification of critically endangered ecosystems among the large extensive forests in the Congo Basin. In particular, the montane and sub-montane forests identified as critically endangered are already limited in extent and have suffered deforestation and degradation, and are home to the Eastern Chimpanzee and Eastern Gorilla habitat, which are endangered and critically endangered species on the IUCN Red List respectively (IUCN, 2019). These habitats are presently within iconic protected areas such as Virungas National Park, which have undergone recent forest loss and threats from oil development, demonstrating the limits of formal protection and World Heritage status in a situation of political instability, high levels of poverty, and conflict (Hochleithner, 2017; United
Nations Economic Commission for Africa, 2015). The other critically endangered habitat identified is currently unprotected and lies between several mining concessions which might present acute threats in the future (Pélissier et al., 2019). Additionally, particular consideration should be given to ecosystems in endangered and vulnerable categories which lie along southern edge of the dense forest ranges. These are likely naturall more fragmented open forests, making them moer susceptible to encroachment by humans and are present among mixed agricultural landscapes and could be sites to focus restoration activities.

\section{Limitations}

All metrics or approximations such as indirect methods or proxies come with the risk of oversimplifying or missing crucial detail that one might observe with direct methods, or for example observing forest degradation events with very high-resolution imagery. FC relies on accurate forest cover maps, which are not always possible with limited validation or available quality data, or at regional scales that can be affected by varying forest definitions. For example, the global forest cover maps from Hansen et al. (2013), which are most often used due to access, consistency, resolution, can be difficult to harmonize at the regional global scale because the forest cover threshold varies by latitude, along with different country definitions of forest (Romijn et al., 2013). For this reason, we developed forest ecosystem maps integrating data from various sources and validated with expert opinion to limit bias from one dataset.

FC is a relative index based on biomass estimations, which will always include an element of uncertainty. We overcome this by not using AGB data directly, but rather averaged over forest strata, which should minimize any large errors or inconsistencies, unless most of the ecosystem is already degraded. We base our assessment on the assumption that the maximum potential biomass is present in intact, core forest - this can be hindered by the quality of the AGB map, or ecosystems that are so severely degraded that no core forest area exist. Additionally, as the changes in biomass are relative, the actual biomass estimates do not necessarily bias the final condition estimate to a great extent - if biomass is generally over or under-estimated the condition value is not affected. Next, the estimate of maximum potential FC depends on the biomass of forest types at an initial, presumably intact state. For forest types which are already degraded or have low biomass initially based, subsequent condition estimates will be related. For this reason, we recommend that the forest condition index in tandem with the transition classes to adequately identify the current state in the potential degradation time series.

\subsection{Future work/implications}

Detecting changes in forest cover condition and degradation alone does not meet all the needs for management in the face of increasing population and threats, and new drivers of changing climate. A further step in the analysis is to undertake a geo-spatial assessment of drivers of degradation, to support better land planning and mitigation strategies. An assessment of shifting cultivation drivers and change is provided by Molinario et al. (2015) which adds a further relevant level of refinement to assign types of transitions to drivers or assess post deforestation land covers. A more in-depth analysis of the complex interactions and changes in drivers over time could provide a finer assessment to manage the causes of deforestation in DRC and define and project future risks and scenario assessment.

\section{Conclusions}

The outlined approach to assessing FC has provided a consistent and repeatable tool for evaluating forest over time allowing us to distinguish stable, degenerating and regenerating forest via a continuous metric, according to a biomass definition of forest degradation. We have shown 


\begin{tabular}{|c|c|c|c|c|c|c|c|c|c|c|c|c|}
\hline $\begin{array}{c}\text { General Forest } \\
\text { Type } \\
\end{array}$ & Code & $\begin{array}{r}\text { Forest Type } \\
\text { Extent } 2000 \\
\text { (ha) }\end{array}$ & $\begin{array}{r}\text { Forest Type } \\
\text { Extent } 2016 \\
\text { (ha) } \\
\end{array}$ & Mean FC & $\begin{array}{c}\text { A2b } \\
\text { (adjusted \% } \\
\text { PRD) }\end{array}$ & $\begin{array}{r}\text { B1 Extent } \\
(\mathrm{km} 2)\end{array}$ & $\begin{array}{l}\text { B2 Area } \\
\text { ( } 1 \% \text { rule) }\end{array}$ & \begin{tabular}{|c|} 
D2a affected \\
extent (\% PRD \\
core forest in \\
$2050)$ \\
\end{tabular} & $\begin{array}{l}\text { D2a severity } \\
\text { (\% PRD forest } \\
\text { condition } \\
\text { 2050) }\end{array}$ & $\begin{array}{l}\text { D3 extent } \\
\text { (\% core } \\
\text { forest loss } \\
\text { since 1850) }\end{array}$ & $\begin{array}{l}\text { D3 Severity } \\
\text { (condition } \\
\text { lost since } \\
1850 \text { ) } \\
\end{array}$ & $\begin{array}{l}\text { Final } \\
\text { Threat } \\
\text { Status }\end{array}$ \\
\hline \multirow[t]{9}{*}{$\begin{array}{l}\text { Dense } \\
\text { Evergreen }\end{array}$} & 11320 & 1,414 & 1,332 & 28.06 & 28.27 & 117,779 & 6 & 87.37 & 90.44 & 84.79 & 71.94 & CR \\
\hline & 11340 & 64,235 & 63,176 & 72.37 & 9.08 & 31,391 & 44 & 61.73 & 51.95 & 40.31 & 27.63 & Vu \\
\hline & 12120 & 127,724 & 115,908 & 64.84 & 39.05 & $1,252,571$ & 401 & 48.35 & 48.72 & 64.66 & 35.16 & Vu \\
\hline & 12130 & 293,166 & 271,207 & 42.66 & 31.97 & $1,226,900$ & 939 & 55.08 & 68.77 & 79.15 & 57.34 & Vu \\
\hline & 12140 & $3,683,258$ & $3,652,941$ & 85.91 & 3.84 & $1,805,672$ & 2523 & 25.36 & 25.99 & 19.49 & 14.09 & LC \\
\hline & 12220 & 114,911 & 113,699 & 91.76 & 4.25 & 453,124 & 135 & 20.03 & 18.00 & 11.15 & 8.24 & LC \\
\hline & 12240 & 26,543 & 26,321 & 84.10 & 4.70 & 107,017 & 46 & 39.95 & 38.58 & 19.36 & 15.90 & Vu \\
\hline & 12320 & 185,738 & 180,869 & 76.07 & 11.85 & 167,546 & 121 & 45.80 & 46.44 & 29.46 & 23.93 & LC \\
\hline & 12340 & 3,012 & 2,980 & 66.67 & 6.01 & 22,156 & 9 & 48.99 & 54.95 & 41.70 & 33.33 & EN \\
\hline \multirow{7}{*}{$\begin{array}{l}\text { Evergren and } \\
\text { Semi- } \\
\text { Deciduous }\end{array}$} & 22120 & $1,662,006$ & $1,650,651$ & 95.67 & 3.21 & $1,219,257$ & 1318 & 9.13 & 8.85 & 7.31 & 4.33 & LC \\
\hline & 22130 & 385,836 & 369,374 & 65.22 & 19.48 & $1,200,163$ & 1059 & 42.08 & 51.35 & 48.55 & 34.78 & LC \\
\hline & 22140 & $14,915,844$ & $14,765,946$ & 89.80 & 5.04 & $1,886,996$ & 5450 & 31.47 & 26.16 & 14.40 & (cotroed or & next(@age) \\
\hline & 22220 & $1,029,960$ & $1,023,036$ & 96.01 & 2.77 & 287,906 & 467 & 15.59 & 11.97 & 5.92 & 3.99 & LC \\
\hline & 22240 & 33,597 & 33,319 & 83.98 & 4.44 & 235,436 & 69 & 36.85 & 33.29 & 23.31 & 16.02 & LC \\
\hline & 22320 & 258,645 & 247,788 & 72.36 & 19.49 & 111,203 & 197 & 60.09 & 58.63 & 33.33 & 27.64 & Vu \\
\hline & 22340 & 5,138 & 5,109 & 59.92 & 2.52 & 35,930 & 14 & 31.30 & 48.28 & 50.04 & 40.08 & EN \\
\hline \multirow{9}{*}{$\begin{array}{c}\text { Semi- } \\
\text { Deciduous }\end{array}$} & 31110 & $1,577,743$ & $1,549,357$ & 71.65 & 7.84 & 193,021 & 701 & 27.20 & 38.61 & 41.60 & 28.35 & LC \\
\hline & 31120 & $29,266,061$ & $27,585,817$ & 80.90 & 24.46 & $1,279,272$ & 5896 & 44.44 & 42.17 & 26.97 & 19.10 & LC \\
\hline & 31130 & $13,376,916$ & $12,696,521$ & 84.12 & 23.18 & 961,081 & 3664 & 44.45 & 38.95 & 22.86 & 15.88 & LC \\
\hline & 31140 & $37,851,190$ & $37,051,712$ & 85.30 & 10.24 & $1,924,336$ & 7737 & 41.80 & 35.57 & 21.42 & 14.70 & LC \\
\hline & 31220 & 498,705 & 454,093 & 61.88 & 34.18 & 369,112 & 392 & 80.45 & 72.88 & 53.28 & 38.12 & EN \\
\hline & 31240 & 75,450 & 74,388 & 73.36 & 7.09 & 252,923 & 89 & 55.07 & 47.77 & 41.55 & 26.64 & LC \\
\hline & 31320 & 129,090 & 116,523 & 46.47 & 41.88 & 111,092 & 142 & 88.86 & 87.53 & 61.91 & 53.53 & CR \\
\hline & 31340 & 14,949 & 14,806 & 62.51 & 4.96 & 39,374 & 27 & 39.95 & 54.97 & 45.78 & 37.49 & VU \\
\hline & 32120 & $8,740,924$ & $8,627,203$ & 95.31 & 6.48 & 911,114 & 2573 & 19.21 & 14.07 & 7.64 & 4.69 & LC \\
\hline
\end{tabular}




\begin{tabular}{|c|c|c|c|c|c|c|c|c|c|c|c|c|c|c|}
\hline & 32130 & $10,705,2$ & 10,59 & 2,702 & 94.12 & 5.23 & $1,166,921$ & 4396 & 14.98 & 14.22 & \multicolumn{2}{|c|}{8.27} & 5.88 & LC \\
\hline & 32140 & $3,190,2$ & 3,13 & 6,105 & 83.83 & 7.68 & $1,019,159$ & 3006 & 44.24 & 38.61 & \multicolumn{2}{|c|}{22.30} & 16.17 & LC \\
\hline & 32220 & 810,4 & & 3,165 & 85.19 & 14.73 & 428,420 & 560 & 48.36 & 39.39 & \multicolumn{2}{|c|}{21.77} & 14.81 & LC \\
\hline & 32240 & 10,6 & & 0,557 & 82.60 & 5.10 & 200,429 & 35 & 47.46 & 36.06 & \multicolumn{2}{|c|}{29.31} & 17.40 & VU \\
\hline & 32320 & 208,4 & & 2,664 & 63.42 & 33.72 & 110,475 & 197 & 76.22 & 73.76 & \multicolumn{2}{|c|}{43.57} & 36.58 & VU \\
\hline & 32340 & 2,1 & & 2,103 & 72.88 & 3.45 & 18,753 & 5 & 49.69 & 48.41 & \multicolumn{2}{|c|}{36.81} & 27.12 & EN \\
\hline \begin{tabular}{c|} 
Semi- \\
\end{tabular} & 42120 & $3,213,2$ & 2,94 & 9,922 & 74.20 & 34.01 & 489,205 & 1677 & 60.99 & 57.02 & \multicolumn{2}{|c|}{34.68} & 25.80 & VU \\
\hline Pioneer & 42130 & $17,198,8$ & 16,02 & 7,875 & 78.18 & 28.97 & $1,194,308$ & 5693 & 43.40 & 43.08 & \multicolumn{2}{|c|}{30.27} & 21.82 & LC \\
\hline & 42140 & $2,467,0$ & 2,34 & 2,183 & 59.96 & 22.49 & 869,131 & 1485 & 73.78 & 72.83 & \multicolumn{2}{|c|}{47.95} & 40.04 & VU \\
\hline & 42220 & 349,1 & & 6,814 & 58.47 & 35.93 & 300,419 & 410 & 83.70 & 77.44 & \multicolumn{2}{|c|}{55.43} & 41.53 & EN \\
\hline & 42230 & & 22 & 901 & 80.32 & 12.73 & 10,118 & 1 & 39.35 & 21.75 & \multicolumn{2}{|c|}{81.24} & 19.68 & CR \\
\hline & 42240 & 6,4 & & 6,351 & 71.81 & 9.67 & 41,384 & 20 & 62.28 & 59.80 & \multicolumn{2}{|c|}{34.52} & 28.19 & VU \\
\hline & 42320 & 180,4 & & 0,827 & 42.89 & 45.23 & 167,140 & 208 & 89.20 & 88.59 & \multicolumn{2}{|c|}{66.03} & 57.11 & CR \\
\hline & 42340 & 2,3 & & 2,291 & 76.70 & 9.58 & 6,542 & 3 & 67.44 & 54.46 & \multicolumn{2}{|c|}{33.85} & 23.30 & EN \\
\hline Swamp Forest & 63151 & $4,537,0$ & 4,068 & 8,227 & 70.64 & 42.14 & 376,553 & 2433 & 74.67 & 67.72 & \multicolumn{2}{|c|}{38.91} & 29.36 & $\mathrm{Vu}$ \\
\hline & 63152 & $6,036,5$ & 5,94 & 5,728 & 92.42 & 7.41 & 369,866 & 2447 & 25.52 & 22.60 & \multicolumn{2}{|c|}{9.63} & 7.58 & LC \\
\hline & 63153 & $1,783,4$ & 1,75 & 3,679 & 89.16 & 8.00 & 380,728 & 1571 & 32.24 & 28.34 & \multicolumn{2}{|c|}{14.52} & 10.84 & LC \\
\hline & 63154 & 817,3 & & 1,088 & 69.32 & 9.29 & 368,573 & 909 & 49.86 & 50.93 & \multicolumn{2}{|c|}{39.79} & 30.68 & LC \\
\hline & 63155 & $1,033,9$ & 1,02 & 3,902 & 91.32 & 5.11 & 266,923 & 896 & 29.38 & 25.94 & \multicolumn{2}{|c|}{10.55} & 8.68 & LC \\
\hline & 63156 & $1,548,1$ & $1,54 C$ & 0,305 & 94.45 & 2.72 & 266,485 & 824 & 19.38 & 16.73 & \multicolumn{2}{|c|}{6.97} & 5.55 & LC \\
\hline & 63157 & 311,1 & & 7,660 & 86.97 & 5.92 & 251,245 & 386 & 33.06 & 30.52 & \multicolumn{2}{|c|}{18.05} & 13.03 & LC \\
\hline & 63161 & $1,671,2$ & 1,498 & 8,735 & 70.73 & 41.92 & 480,285 & 1190 & 72.39 & 65.72 & \multicolumn{2}{|c|}{39.41} & 29.27 & VU \\
\hline & 63162 & $4,642,8$ & 4,54 & 1,822 & 89.57 & 10.07 & 490,315 & 1842 & 32.90 & 29.59 & & & 10.43 & LC \\
\hline & 63163 & $3,205,7$ & 3,16 & 4,469 & 91.21 & 5.84 & 490,983 & 1652 & 25.38 & 22.87 & & & 8.79 & LC \\
\hline & 63164 & $1,142,6$ & 1,12 & 4,208 & 68.33 & 7.22 & 457,531 & 959 & 51.62 & 49.48 & & & 31.67 & VU \\
\hline & 63165 & 554,4 & & 6,680 & 92.41 & 6.44 & 288,024 & 691 & 25.78 & 22.84 & & & 7.59 & LC \\
\hline & 63166 & $2,014,1$ & 2,00 & 3,064 & 96.19 & 2.72 & 292,569 & 870 & 13.08 & 11.65 & & & 3.81 & LC \\
\hline & 63167 & 209,9 & & 6,923 & 83.96 & 6.59 & 292,902 & 396 & 35.04 & 33.51 & & & 16.04 & LC \\
\hline Open Forest & 81110 & $9,077,4$ & 8,91 & 2,775 & 19.40 & 8.12 & $1,623,726$ & 6243 & 55.48 & 88.32 & & & 80.60 & EN \\
\hline & 81120 & $7,915,8$ & 7,28 & 7,374 & 21.79 & 31.61 & $1,051,266$ & 4280 & 66.17 & 76.39 & & & 78.21 & EN \\
\hline & 81140 & $2,752,083$ & $2,585,455$ & 19.26 & 26.52 & $2,773,294$ & 2570 & 56.22 & 85.19 & 95.00 & 80.74 & EN & & \\
\hline & 81220 & 577,782 & 544,560 & 22.52 & 23.91 & 205,313 & 431 & 64.98 & 82.46 & 97.06 & 77.48 & EN & & \\
\hline & 81240 & 85,797 & 85,004 & 21.58 & 4.39 & 261,394 & 136 & 51.30 & 81.04 & 96.18 & 78.42 & EN & & \\
\hline & 81320 & 282,233 & 263,227 & 14.00 & 28.64 & 80,439 & 229 & 70.74 & 88.77 & 98.32 & 86.00 & EN & & \\
\hline & 81340 & 38,659 & 38,139 & 18.41 & 5.67 & 90,736 & 62 & 30.56 & 82.49 & 95.91 & 81.59 & EN & & \\
\hline & 82130 & $10,614,508$ & $9,686,379$ & 16.25 & 34.14 & $1,967,561$ & 8913 & 70.42 & 86.99 & 98.92 & 83.75 & EN & & \\
\hline & 82230 & 551,822 & 540,422 & 18.26 & 9.61 & 908,869 & 846 & 35.67 & 82.29 & 99.56 & 81.74 & EN & & \\
\hline Mangrove & 71140 & 404,083 & 401,897 & 64.71 & 2.54 & 224,232 & 174 & 29.77 & 43.69 & 45.02 & 35.29 & LC & & \\
\hline Marantacae & 51140 & 270,382 & 265,991 & 91.71 & 8.00 & 33,354 & 188 & 33.88 & 22.58 & 15.40 & 8.29 & LC & & \\
\hline
\end{tabular}




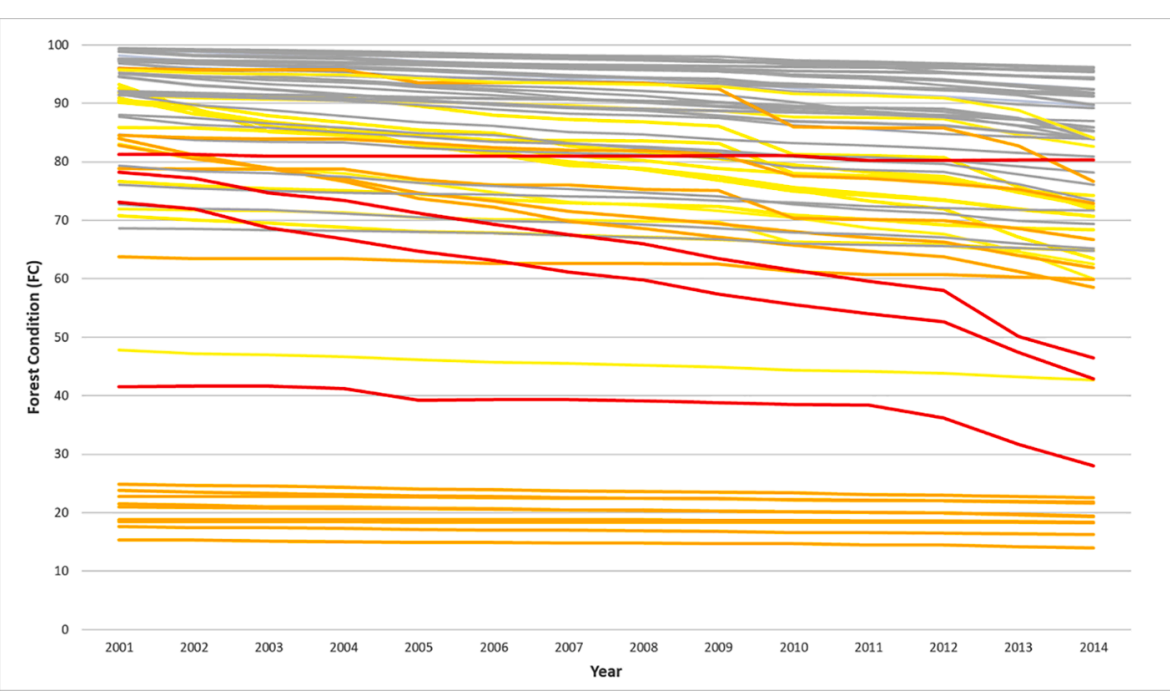

Fig. 11. Annual FC of each forest type; grouped into colors according to red list classification (Fig. 10). (For interpretation of the references to color in this figure legend, the reader is referred to the web version of this article.)

that the amount of intact forest in the Congo Basin has decreased from $78 \%$ in 2000 to $67 \%$ in 2016 with over 24 million hectares of forest degraded in that time period. FC is inversely correlated with canopy gap density, and positively correlated with cumulative NBR anomalies. We demonstrate the application for ecosystem Red Listing, using FC to identify potential ecosystem collapse, and found 4 critically endangered forest ecosystems in the DRC. We demonstrate that for understanding the threatened status of ecosystems, quantifying condition can be just as important as understanding its change in extent or rarity. We propose to integrate FC into future conservation assessment and prioritization approaches.

Author contributions

A.S., H.G., V.G., D.B., O.R. conceptualized and developed the forest ecosystem map and associated regional datasets. A.S. and H.G. developed the forest condition metric, N.A.A. supported A.S. for the biomass and fragmentation assessments; A.S., H.G., N.M and O.R. evaluated the ecosystem data for the risk assessments; O.R. led the project design, coordination and funding acquisition. A.S. wrote the original draft manuscript, H.G., V.G., D.B., N.A.A., N.M., O.R. edited and reviewed.

\section{Declaration of Competing Interest}

The authors declare that they have no known competing financial interests or personal relationships that could have appeared to influence the work reported in this paper.

\section{Acknowledgements}

This work was initiated and coordinated by the Congo basin office of the Forest Stewardship Council (FSC) in the context of their High Conservation Value Roadmap project funded by the Central African Forests Commission (COMIFAC) through its Programme for the Promotion of Certified Logging (PPECF). The authors wish to thank the Forest Stewardship Council for having created the arena for the collaboration between CIRAD, WCS, WWF Germany and WRI. We would also like to express our thanks to WWF-US who supported the organization of the key workshop that brought the authors of this work together, as well as the German Federal Ministry of the Environment, Nature Conservation and Nuclear Safety and the KfW Development Bank for supporting the development of the national carbon map for DRC and associated LiDAR data collection.

\section{Appendix A. Supplementary data}

Supplementary data to this article can be found online at https://doi. org/10.1016/j.ecolind.2020.107268.

\section{References}

Avitabile, V., Herold, M., Heuvelink, G., Lewis, S., Phillips, O., Asner, G.P., Armston, J., Asthon, P., Banin, L., Bayol, N., Berry, N., Boeckx, P., de Jong, B., DeVries, B., Girardin, C., Kearsley, E., Lindsell, J., Lopez-Gonzalez, G., Lucas, R., Malhi, Y., Morel, A., Mitchard, D., Nagy, L., Qie, L., Quinones, M., Ryan, C., Slik, F., Sunderland, T., Vaglio Laurin, G., Velentini, R., Verbeeck, H., Wijaya, A., Willcock, S., 2016. An integrated pan-tropical biomass map using multiple reference datasets. Global Change Biol. 22 https://doi.org/10.1111/gcb.13139. In this issue.

Bastin, J.-F., Berrahmouni, N., Grainger, A., Maniatis, D., Mollicone, D., Moore, R., Patriarca, C., Picard, N., Sparrow, B., Abraham, E.M., Aloui, K., Atesoglu, A., Attore, F., Bassüllü, Ç., Bey, A., Garzuglia, M., García-Montero, L.G., Groot, N., Guerin, G., Laestadius, L., Lowe, A.J., Mamane, B., Marchi, G., Patterson, P., Rezende, M., Ricci, S., Salcedo, I., Diaz, A.-P., Stolle, F., Surappaeva, V., Castro, R., 2017. The extent of forest in dryland biomes. Science 356 (6338), 635-638. https:// doi.org/10.1126/science:aam6527.

Betbeder, J., Gond, V., Frappart, F., Baghdadi, N., Briant, G., Bartholomes, E., 2014. Mapping of central africa forested wetlands using remote sensing. IEEE J. Sel. Top. Appl. Earth Obs. Remote Sens. 7, 531-542. https://doi.org/10.1109/JS.

Betts, M.G., Wolf, C., Pfeifer, M., Banks-Leite, C., Arroyo-Rodríguez, V., Ribeiro, D.B., Barlow, J., Eigenbrod, F., Faria, D., Fletcher Jr., R.J., Hadley, A.S., Hawes, J.E., Holt, R.D., Klingbeil, B., Kormann, U., Lens, L., Levi, T., Medina-Rangel, G.F., Melles, S.L., Mezger, D., Morante-Filho, J.C., Orme, C.D.L., Peres, C.A., Phalan, B.T., Pidgeon, A., Possingham, H., Ripple, W.J., Slade, E.M., Somarriba, E., Tobias, J.A., Tylianakis, J.M., Urbina-Cardona, J.N., Valente, J.J., Watling, J.I., Wells, K., Wearn, O.R., Wood, E., Young, R., Ewers, R.M., 2019. Extinction filters mediate the global effects of habitat fragmentation on animals. Science 366 (6470), 1236-1239. https://doi.org/10.1126/science:aax9387.

Birdlife International, 2018. World Database of Key Biodiversity Areas. BirdLife Int.

Bland, J.M., Altman, D.G., 1995. Tukey Multiple Comparison test. Br. Med. J. J. Clin. Nurs.

Bland, L.M., Keith, D.A., Miller, R.M., Murray, N.J., Rodríguez, J.., 2015. Guidelines for the application of IUCN Red List of ecosystems categories and criteria. IUCN International Union for Conservation of Nature. https://doi.org/10.2305/IUCN. CH.2016.RLE.1.en.

Bland, L., Regan, T., Dinh, M., Ferrari, R., Keith, D., Lester, R., Mouillot, D., Murray, N., Nguyen, H.A., Nicholson, E., 2017. Using multiple lines of evidence to assess the risk of ecosystem collapse. Proc. R. Soc. B Biol. Sci. 284 https://doi.org/10.1098/ rspb.2017.0660. In this issue.

Broadbent, E.N., Asner, G.P., Keller, M., Knapp, D.E., Oliveira, P.J.C., Silva, J.N., 2008. Forest fragmentation and edge effects from deforestation and selective logging in the Brazilian Amazon. Biol. Conserv. 141 (7), 1745-1757. https://doi.org/10.1016/j. biocon.2008.04.024.

Brooks, T.M., Mittermeier, R.A., da Fonseca, G.A.B., Gerlach, J., Hoffmann, M., Lamoreux, J.F., Mittermeier, C.G., Pilgrim, J.D., Rodrigues, A.S.L., 2006. Global biodiversity conservation priorities. Science 313 (5783), 58-61. https://doi.org/ 10.1126/science:1127609.

Bucki, M., Cuypers, D., Mayaux, P., Achard, F., Estreguil, C., Grassi, G., 2012. Assessing REDD+ performance of countries with low monitoring capacities: the matrix 
approach. Environ. Res. Lett. 7 (1), 014031. https://doi.org/10.1088/1748-9326/7/ $1 / 014031$.

Chaplin-Kramer, R., Ramler, I., Sharp, R., Haddad, N.M., Gerber, J.S., West, P.C., Mandle, L., Engstrom, P., Baccini, A., Sim, S., Mueller, C., King, H., 2015. Degradation in carbon stocks near tropical forest edges. Nat. Commun. 6, 10158 https://doi.org/10.1038/ncomms10158.

Cohen, W.B., Yang, Z., Kennedy, R., 2010. Detecting trends in forest disturbance and recovery using yearly Landsat time series: 2 . TimeSync - Tools for calibration and validation. Remote Sens. Environ. 114 (12), 2911-2924. https://doi.org/10.1016/j. rse.2010.07.010.

Dargie, G.C., Lewis, S.L., Lawson, I.T., Mitchard, E.T.A., Page, S.E., Bocko, Y.E., Ifo, S.A., 2017. Age, extent and carbon storage of the central Congo Basin peatland complex. Nature 542 (7639), 86-90. https://doi.org/10.1038/nature21048.

Dargie, G.C., Lawson, I.T., Rayden, T.J., Miles, L., Mitchard, E.T.A., Page, S.E., Bocko, Y E., Ifo, S.A., Lewis, S.L., 2019. Congo Basin peatlands: threats and conservation priorities. Mitig Adapt Strateg Glob Change 24 (4), 669-686. https://doi.org/ 10.1007/s11027-017-9774-8

DeVries, B., Verbesselt, J., Kooistra, L., Herold, M., 2015. Robust monitoring of smallscale forest disturbances in a tropical montane forest using Landsat time series. Remote Sens. Environ. 161, 107-121. https://doi.org/10.1016/j.rse.2015.02.012.

Díaz, S., Settele, J., Brondízio, E., Ngo, H.T., Guèze, M., Agard, J., Arneth, A., Balvanera, P., Brauman, K., Butchart, S., Chan, K., Garibaldi, L., Ichii, K., Liu, J., Subramanian, S.M., Midgley, G., Miloslavich, P., Molnár, Z., Obura, D., Pfaff, A. Polasky, S., Purvis, A., Razzaque, J., Reyers, B., Chowdhury, R.R., Shin, Y.-J., Visseren-Hamakers, I., Willis, K., Zayas, C., 2019. Summary for policymakers of the global assessment report on biodiversity and ecosystem services of the Intergovernmental Science-Policy Platform on Biodiversity and Ecosystem Services. United Nations.

Feeley, K.J., Terborgh, J.W., 2005. The effects of herbivore density on soil nutrients and tree growth in tropical forest fragments. Ecology 86 (1), 116-124. https://doi.org/ 10.1890/03-0657.

Foga, S., Scaramuzza, P.L., Guo, S., Zhu, Z., Dilley Jr, R.D., Beckmann, T., Schmidt, G.L., Dwyer, J.L., Joseph Hughes, M., Laue, B., 2017. Cloud detection algorithm comparison and validation for operational Landsat data products. Remote Sens. Environ. 194, 379-390. https://doi.org/10.1016/j.rse.2017.03.026.

Foley, J.A., Defries, R., Asner, G.P., Barford, C., Bonan, G., Carpenter, S.R., Chapin, F.S., Coe, M.T., Daily, G.C., Gibbs, H.K., Helkowski, J.H., Holloway, T., Howard, E.A., Kucharik, C.J., Monfreda, C., Patz, J.A., Prentice, I.C., Ramankutty, N., Snyder, P.K., 2005. Global consequences of land use. Science 309, 570-574.

Forest Carbon Partnership Facility (FCPF); 2018. People and Forests - A Sustainable Forest Management-Based Emission Reduction Program in the Terai Arc Landscape, Nepal.

Gascon, C., Williamson, G.B., Da Fonseca, G.A.B., 2000. Receding forest edges and vanishing reserves. Science 80-. https://doi.org/10.1126/science.288.5470.1356.

Ghazoul, Jaboury, Burivalova, Zuzana, Garcia-Ulloa, John, King, Lisa A., 2015 Conceptualizing forest degradation. Trends Ecol. Evol. 30 (10), 622-632. https:// doi.org/10.1016/j.tree.2015.08.001.

Giri, C., Ochieng, E., Tieszen, L.L., Zhu, Z., Singh, A., Loveland, T., Masek, J., Duke, N., 2011. Status and distribution of mangrove forests of the world using earth observation satellite data. Global Ecol. Biogeogr. 20 https://doi.org/10.1111/ j.1466-8238.2010.00584.x. In this issue.

Gorelick, Noel, Hancher, Matt, Dixon, Mike, Ilyushchenko, Simon, Thau, David, Moore, Rebecca, 2017. Google earth engine: planetary-scale geospatial analysis for everyone. Remote Sens. Environ. 202, 18-27. https://doi.org/10.1016/j rse.2017.06.031.

Grantham, Hedley S, Dundan, A., Evans, T.D., 2020. Only $40 \%$ of the world's forests are in good health. Sci. Adv. 1-18 https://doi.org/10.1101/2020.03.05.978858.

Grantham, H.S., Shapiro, A., Bonfils, D., Gond, V., Goldman, E., Maisels, F., Plumptre, A J.J., Rayden, T., Robinson, J.G.G., Strindberg, S., Stokes, E., Tulloch, A.I.T.T., Watson, J.E.M.E.M., Williams, L., Rickenbach, O., 2020. Spatial priorities for conserving the most intact biodiverse forests within Central Africa. Environ. Res. Lett. 15, 0940b5. https://doi.org/10.1088/1748-9326/ab9fae.

Haddad, N., Brudvig, L.A., Clobert, J., Davies, K.F., Gonzalez, A., Holt, R.D., Lovejoy, T. E., Sexton, J.O., Austin, M.P., Collins, C.D., Cook, W.M., Damschen, E.I., Ewers, R. M., Foster, B.L., Jenkins, C.N., King, A.J., Laurance, W.F., Levey, D.J., Margules, C. R., Melbourne, B.A., Nicholls, A.O., Orrock, J.L., Song, D.D.-X., Townshend, J.R., 2015. Habitat fragmentation and its lasting impact on Earth's ecosystems. Sci. Adv. 1, 1-9. https://doi.org/10.1126/sciadv.1500052.

Hansen, M., Potapov, P., Moore, R., Hancher, M., Turabanova, S., Tyukavina, A., Thau, D., Stehman, S., Goetz, S., Loveland, T., Kommareddy, A., Egorov, A., Chini, L., Justice, C., Townshend, J., 2013. High-resolution global maps of 21stcentury forest cover change. Science 342, 850-853. http://www.ncbi.nlm.nih.gov/p ubmed/24233722 In this issue.

Harper, Karen A., Ellen Macdonald, S., Burton, PHILIP J., Chen, Jiquan,

Brosofske, Kimberley D., Saunders, Sari C., Euskirchen, Eugenie S., Roberts, DAR, Jaiteh, Malanding S., Esseen, Per-Anders, 2005. Edge Influence on Forest Structure and Composition in Fragmented Landscapes. Conserv. Biol. 19 (3), 768-782. https:// doi.org/10.1111/j.1523-1739.2005.00045.x.

Hart, J.A., Detwiler, K.M., Gilbert, C.C., Burrell, A.S., Fuller, J.L., Emetshu, M., Hart, T.B., Vosper, A., Sargis, E.J., Tosi, A.J., 2012. Lesula: A New Species of Cercopithecus Monkey Endemic to the Democratic Republic of Congo and Implications for Conservation of Congo's Central Basin. PLoS One. https://doi.org/10.1371/journal. pone. 0044271

Herold, M., Romàn-Cuesta, R.M., Mollicone, D., Hirata, Y., Van Laake, P., Asner, G.P., Souza, C., Skutsch, M., Avitabile, V., MacDicken, K., 2011. Options for monitoring and estimating historical carbon emissions from forest degradation in the context of REDD+. Carbon Balance Manage. 6, 13. https://doi.org/10.1186/1750-0680-6-13.

Heymell, V., MacDicken, K., Altrell, D., Branthomme, A., Tavan, R., Thompson, I., Nasi, R., Okabe, K., Kapos, V., Gordon, J., Guariguata, M.R., Sabogal, C.,

Chandrasekharan, D., McGarry, D., 2011. Assessing Forest Degradation - towards the development of globally appropriate guidelines. Rome.

Hochleithner, Stephan, 2017. Beyond contesting limits: land, access, and resistance at the Virunga National Park. Conservat Soc 15 (1), 100. https://doi.org/10.4103/ 0972-4923.201397.

IUCN, 2016a. An introduction to the IUCN Red List of Ecosystems: The categories and criteria for assessing risks to ecosystems 14. https://doi.org/10.2305/IUCN. CH.2016.RLE.2.

IUCN, 2016b. A global standard for the identification of Key Biodiversity Areas. IUCN, 2019. The IUCN Red List of Threatened Species. Version 2019-1. [WWW Document]. URL http://www.iucnredlist.org. (accessed 3.21.19).

Jantz, Patrick, Goetz, Scott, Laporte, Nadine, 2014. Carbon stock corridors to mitigate climate change and promote biodiversity in the tropics. Nature Clim. Change 4 (2), 138-142. https://doi.org/10.1038/nclimate2105.

Keith, D.A., Rodríguez, J.P., Rodríguez-Clark, K.M., Nicholson, E., Aapala, K., Alonso, A., Asmussen, M., Bachman, S., Basset, A., Barrow, E.G., Benson, J.S., Bishop, M.J., Bonifacio, R., Brooks, T.M., Burgman, M.A., Comer, P., Comín, F.A., Essl, F., FaberLangendoen, D., Fairweather, P.G., Holdaway, R.J., Jennings, M., Kingsford, R.T., Lester, R.E., Nally, R. Mac, McCarthy, M.A., Moat, J., Oliveira-Miranda, M.A. Pisanu, P., Poulin, B., Regan, T.J., Riecken, U., Spalding, M.D., Zambrano-Martínez, S., 2013. Scientific Foundations for an IUCN Red List of Ecosystems. PLoS One 8, e62111. https://doi.org/10.1371/journal.pone.0062111.

Kennedy, R.E., Yang, Z., Cohen, W.B., 2010. Detecting trends in forest disturbance and recovery using yearly Landsat time series: 1 . LandTrendr - Temporal segmentation algorithms. Remote Sens. Environ. 114, 2897-2910. https://doi.org/10.1016/j. rse.2010.07.008.

Key, C.H., Benson, N.C., 2005. Landscape assessment: remote sensing of severity, the normalized burn ratio and ground measure of severity, the composite burn index. FIREMON Fire Eff. Monit. Invent. Syst. Ogden, Utah USDA For. Serv. Rocky Mt. Res. Stn.

Lagomasino, D., Fatoyinbo, L., Lee, S., Feliciano, E., Trettin, C., Shapiro, A., Mangora, M., 2019. Measuring mangrove carbon loss and gain in deltas. Environ. Res. Lett. 14 https://doi.org/10.1088/1748-9326/aafode. In this issue.

Langner, A., Miettinen, J., Kukkonen, M., Vancutsem, C., Simonetti, D., Vieilledent, G., Verhegghen, A., Gallego, J., Stibig, H.J., 2018. Towards operational monitoring of forest canopy disturbance in evergreen rain forests: A test case in continental Southeast Asia. Remote Sens. 10, 544. https://doi.org/10.3390/rs10040544.

Malhi, Y., Adu-Bredu, S., Asare, R.A., Lewis, S.L., Mayaux, P., 2013. African rainforests: Past, present and future. Philos. Trans. R. Soc. B Biol. Sci. https://doi.org/10.1098/ rstb.2012.0312.

Maxwell, S.L., Evans, T., Watson, J.E.M., Morel, A., Grantham, H., Duncan, A., Harris, N., Potapov, P., Runting, R.K., Venter, O., Wang, S., Malhi, Y., 2019. Degradation and forgone removals increase the carbon impact of intact forest loss by $626 \%$. Sci. Adv. 5, eaax2546. https://doi.org/10.1126/sciadv.aax2546.

Miettinen, Jukka, Stibig, Hans-Jürgen, Achard, Frédéric, 2014. Remote sensing of forest degradation in Southeast Asia-Aiming for a regional view through 5-30 m satellite data. Global Ecol. Conserv. 2, 24-36. https://doi.org/10.1016/j.gecco.2014.07.007.

Mitchell, Anthea L., Rosenqvist, Ake, Mora, Brice, 2017. Current remote sensing approaches to monitoring forest degradation in support of countries measurement, reporting and verification (MRV) systems for REDD+. Carbon Balance Manage. 12 (1) https://doi.org/10.1186/s13021-017-0078-9.

Mittermeier, R.A., Mittermeier, C.G., Brooks, T.M., Pilgrim, J.D., Konstant, W.R., da Fonseca, G.A.B., Kormos, C., 2003. Wilderness and biodiversity conservation. Proc. Natl. Acad. Sci. U.S.A. 100 (18), 10309-10313. https://doi.org/10.1073/ pnas. 1732458100

Molinario, G., Hansen, M.C., Potapov, P. V., 2015. Forest cover dynamics of shifting cultivation in the Democratic Republic of Congo : A remote sensing-based assessment for 2000-2010. Environ. Res. Lett. 10, 15. https://doi.org/10.1088/ 1748-9326/10/9/094009.

Molinario, G., Hansen, M., Potapov, P., Tyukavina, A., Stehman, S., 2020. Contextualizing Landscape-Scale Forest Cover Loss in the Democratic Republic of Congo (DRC) between 2000 and 2015. Land 9, 23. https://doi.org/10.3390/ land9010023.

Morin-Rivat, J., Fayolle, A., Favier, C., Bremond, L., Gourlet-Fleury, S., Bayol, N., Lejeune, P., Beeckman, H., Doucet, J.L., 2017. Present-day central African forest is a legacy of the 19th century human history. Elife 6, e20343. https://doi.org/10.7554/ eLife. 20343.

Murdiyarso, D., Skutsch, M., Guariguata, M., Kanninen, M., 2008. Measuring and monitoring forest degradation for REDD Implications of country circumstances, CIFOR infobrief.

Olson, D., Dinerstein, E., 2001. Terrestrial Ecoregions of the World: A New Map of Life on Earth A new global map of terrestrial ecoregions provides an innovative tool for conserving biodiversity.

Olson, David M., Dinerstein, Eric, 2002. The global 200: priority ecoregions for global conservation. Ann. Mo. Bot. Gard. 89 (2), 199. https://doi.org/10.2307/3298564.

Pan, Y., Birdsey, R., Fang, J., Houghton, R., 2011. A large and persistent carbon sink in the world's forests. Science (80-) 14, 1-11.

Pélissier, C., de Marcken, P., Cherel, E., Mapilanga, J., 2019. Le réseau des aires protégées de la République démocratique du Congo : Évaluation pour sa consolidation et son extension. ICCN, WWF. 
Pelletier, Johanne, Martin, Davy, Potvin, Catherine, 2013. REDD + emissions estimation and reporting: dealing with uncertainty. Environ. Res. Lett. 8 (3), 034009. https:// doi.org/10.1088/1748-9326/8/3/034009.

Pereira, Henrique M., Leadley, Paul W., Proença, Vânia, Alkemade, Rob, Scharlemann, Jörn P.W., Fernandez-Manjarrés, Juan F., Araújo, Miguel B. Balvanera, Patricia, Biggs, Reinette, Cheung, William W.L., Chini, Louise, David Cooper, H., Gilman, Eric L., Guénette, Sylvie, Hurtt, George C., Huntington, Henry P., Mace, Georgina M., Oberdorff, Thierry, Revenga, Carmen, Rodrigues, Patrícia, Scholes, Robert J., Sumaila, Ussif Rashid, Walpole, Matt, 2010. Scenarios for global biodiversity in the 21st century. Science 330 (6010), 1496-1501. https://doi.org/ 10.1126/science: 1196624 .

Pettorelli, Nathalie, Schulte to Bühne, Henrike, Tulloch, Ayesha, Dubois, Grégoire, Macinnis-Ng, Cate, Queirós, Ana M., Keith, David A., Wegmann, Martin, Schrodt, Franziska, Stellmes, Marion, Sonnenschein, Ruth, Geller, Gary N. Roy, Shovonlal, Somers, Ben, Murray, Nicholas, Bland, Lucie, Geijzendorffer, Ilse, Kerr, Jeremy T., Broszeit, Stefanie, Leitão, Pedro J., Duncan, Clare, El Serafy, Ghada, He, Kate S., Blanchard, Julia L., Lucas, Richard, Mairota, Paola, Webb, Thomas J., Nicholson, Emily, Rowcliffe, Marcus, Disney, Mat, 2018. Satellite remote sensing of ecosystem functions: opportunities, challenges and way forward. Remote Sens. Ecol. Conserv. 4 (2), 71-93. https://doi.org/10.1002/rse2.59.

Pfeifer, M., Lefebvre, V., Peres, C.A., Banks-Leite, C., Wearn, O.R., Marsh, C.J., Butchart, S.H.M., Arroyo-Rodríguez, V., Barlow, J., Cerezo, A., Cisneros, L., D'Cruze, N., Faria, D., Hadley, A., Harris, S.M., Klingbeil, B.T., Kormann, U., Lens, L. Medina-Rangel, G.F., Morante-Filho, J.C., Olivier, P., Peters, S.L., Pidgeon, A., Ribeiro, D.B., Scherber, C., Schneider-Maunoury, L., Struebig, M., UrbinaCardona, N., Watling, J.I., Willig, M.R., Wood, E.M., Ewers, R.M., 2017. Creation of forest edges has a global impact on forest vertebrates. Nature 551 (7679), 187-191. https://doi.org/10.1038/nature24457.

Philippon, N., Cornu, G., Monteil, L., Gond, V., Moron, V., Pergaud, J., Sèze, G., Bigot, S., Camberlin, P., Doumenge, C., Fayolle, A., Ngomanda, A., 2018. The light-deficient climates of western Central African evergreen forests. Environ. Res. Lett. https://doi. org/10.1088/1748-9326/aaf5d8.

Potapov, P., Yaroshenko, A., Turubanova, S., Dubinin, M., Laestadius, L., Thies, C. Aksenov, D., Egorov, A., Yesipova, Y., Glushkov, I., Karpachevskiy, M., Kostikova, A., Manisha, A., Tsybikova, E., Zhuravleva, I., 2008. Mapping the world's intact forest landscapes by remote sensing. Ecol. Soc. 13. https://doi.org/10.5751/ES02670-130251.

Potapov, P., Laestadius, L., Yaroshenko, A., Turubanova, S., 2009. Case Studies on Measuring and Assessing Forest Degradation, Global Mapping and Monitoring the Extent of Forest Alteration: The Intact Forest Landscapes Method. Rome.

Potapov, P. V., Turubanova, S.A., Hansen, M.C., Adusei, B., Broich, M., Altstatt, A., Mane, L., Justice, C.O., 2012. Quantifying forest cover loss in Democratic Republic of the Congo, 2000-2010, with Landsat ETM+ data. Remote Sens. Environ. 122, 106-116. https://doi.org/10.1016/j.rse.2011.08.027.

Riddell, M., 2013. Assessing the Impacts of Conservation and Commercial Forestry on Livelihoods in Northern Republic of Congo. Conserv. Soc. 11, 199. https://doi.org/ 10.4103/0972-4923.121002.

Riitters, Kurt, Wickham, James, Costanza, Jennifer K., Vogt, Peter, 2016. A global evaluation of forest interior area dynamics using tree cover data from 2000 to 2012 Landscape Ecol. 31 (1), 137-148. https://doi.org/10.1007/s10980-015-0270-9.

Rodríguez, Jon Paul, Keith, David A., Rodríguez-Clark, Kathryn M., Murray, Nicholas J., Nicholson, Emily, Regan, Tracey J., Miller, Rebecca M., Barrow, Edmund G., Bland, Lucie M., Boe, Kaia, Brooks, Thomas M., Oliveira-Miranda, María A., Spalding, Mark, Wit, Piet, 2015. A practical guide to the application of the IUCN Red List of Ecosystems criteria. Philos. Trans. R. Soc. B 370 (1662), 20140003. https:/ doi.org/10.1098/rstb.2014.0003.

Romijn, Erika, Ainembabazi, John Herbert, Wijaya, Arief, Herold, Martin, Angelsen, Arild, Verchot, Louis, Murdiyarso, Daniel, 2013. Exploring different forest definitions and their impact on developing REDD + reference emission levels: a case study for Indonesia. Environ. Sci. Policy 33, 246-259. https://doi.org/10.1016/j. envsci. 2013.06.002.

Sasaki, N., Putz, F.E., 2009. Critical need for new definitions of "forest" and "forest degradation" in global climate change agreements. Conserv. Lett. 2, 226-232.

Shapiro, A.C., Aguilar-Amuchastegui, N., Hostert, P., Bastin, J.F.J.-F., 2016. Using fragmentation to assess degradation of forest edges in Democratic Republic of Congo. Carbon Balance Manag. 11. https://doi.org/10.1186/s13021-016-0054-9.

Shvidenko, A., Barber, C. V., Persson, R., 2005. Forest and Woodland Systems (Current State and Trends Assessment), Current State \& Trends Assessment of the Millennium Assessment.
Silva Junior, C.H.L., Aragão, L.E.O.C., Anderson, L.O., Fonseca, M.G., Shimabukuro, Y.E., Vancutsem, C., Achard, F., Beuchle, R., Numata, I., Silva, C.A., Maeda, E.E., Longo, M., Saatchi, S.S., 2020. Persistent collapse of biomass in Amazonian forest edges following deforestation leads to unaccounted carbon losses. Sci. Adv. 6, eaaz8360. https://doi.org/10.1126/sciadv.aaz8360.

Soille, Pierre, Vogt, Peter, 2009. Morphological segmentation of binary patterns. Pattern Recogn. Lett. 30 (4), 456-459. https://doi.org/10.1016/j.patrec.2008.10.015.

Souza Jr., Carlos M., Roberts, Dar A., Cochrane, Mark A., 2005. Combining spectral and spatial information to map canopy damage from selective logging and forest fires. Remote Sens. Environ. 98 (2-3), 329-343. https://doi.org/10.1016/j. rse.2005.07.013.

Spruce, J.P., Sader, S., Ryan, R.E., Smoot, J., Kuper, P., et al., 2011. Assessment of MODIS NDVI time series data products for detecting forest defoliation by gypsy moth outbreaks. Remote Sens. Environ. 115427-437 115, 427-437.

Stokstad, E., 2014. The empty forest. Science (80-.). https://doi.org/10.1126/ science.345.6195.396.

Takemoto, H., Kawamoto, Y., Furuichi, T., 2015. How did bonobos come to range south of the congo river? Reconsideration of the divergence of Pan paniscus from other Pan populations. Evol. Anthropol. 24, 170-184. https://doi.org/10.1002/evan.21456.

Thompson, I.D., Okabe, K., Tylianakis, J.M., Kumar, P., Brockerhoff, E.G., Schellhorn, N. A., Parrotta, J.A., Nasi, R., 2011. Forest biodiversity and the delivery of ecosystem goods and services: translating science into policy. Bioscience 61, 972-981. https:// doi.org/10.1525/bio.2011.61.12.7.

Thompson, I.D., Guariguata, M.R., Okabe, Kimiko, Bahamondez, Carlos, Nasi, Robert, Heymell, Victoria, Sabogal, Cesar, Okabe, K., Bahamondez, C., Nasi, R., Heymell, V., Sabogal, C., 2013. An operational framework for defining and monitoring forest degradation. Ecol. Soc. 18, 16.

Tittmann, P., Saatchi, S., Sharma, B., 2015. VT0005: Tool for measuring aboveground live forest biomass using remote sensing.

Tyukavina, A., Hansen, M.C., Potapov, P.V., Krylov, A.M., Goetz, S.J., 2016. Pan-tropical hinterland forests: mapping minimally disturbed forests. Glob. Ecol. Biogeogr. 25, 151-163. https://doi.org/10.1111/geb.12394.

United Nations Economic Commission for Africa, 2015. Conflicts in the Democratic Republic of Congo: Causes, impacts and implications for the Great Lakes region. https://doi.org/10.1109/IDEAS.2002.1029674.

Venter, O., Sanderson, E.W., Magrach, A., Allan, J.R., Beher, J., Jones, K.R., Possingham, H.P., Laurance, W.F., Wood, P., Fekete, B.M., Levy, M.A., Watson, J.E. M.M., 2016. Sixteen years of change in the global terrestrial human footprint and implications for biodiversity conservation. Nat. Commun. 7, 12558. https://doi.org/ 10.1038/ncomms12558.

Verbesselt, J., Hyndman, R., Newnham, G., Culvenor, D., 2010. Detecting trend and seasonal changes in satellite image time series. Remote Sens. Environ. 114, 106-115. https://doi.org/10.1016/j.rse.2009.08.014.

Verbesselt, J., Zeileis, A., Herold, M., 2012. Near real-time disturbance detection using satellite image time series. Remote Sens. Environ. 123, 98-108. https://doi.org/ 10.1016/J.RSE.2012.02.022.

Verhegghen, A., Mayaux, P., De Wasseige, C., Defourny, P., 2012. Mapping Congo Basin vegetation types from $300 \mathrm{~m}$ and $1 \mathrm{~km}$ multi-sensor time series for carbon stocks and forest areas estimation. Biogeosciences 9, 5061-5079. https://doi.org/10.5194/bg9-5061-2012.

Vogt, P., Riitters, K., 2017. GuidosToolbox: universal digital image object analysis. Eur. J. Remote Sens. 50, 352-361. https://doi.org/10.1080/22797254.2017.1330650.

Watson, J.E.M.M., Evans, T., Venter, O., Williams, B., Tulloch, A., Stewart, C., Thompson, I., Ray, J.C., Murray, K., Salazar, A., McAlpine, C., Potapov, P., Walston, J., Robinson, J.G., Painter, M., Wilkie, D., Filardi, C., Laurance, W.F., Houghton, R.A., Maxwell, S., Grantham, H., Samper, C., Wang, S., Laestadius, L., Runting, R.K., Silva-Chávez, G.A., Ervin, J., Lindenmayer, D., 2018. The exceptional value of intact forest ecosystems. Nat. Ecol. Evol. 2, 599-610. https://doi.org/ 10.1038/s41559-018-0490-x.

World Resources Institute, 2019. Water | World Resources Institute [WWW Document]. URL http://www.wri.org/our-work/topics/water (accessed 1.16.19).

Xu, L., Saatchi, S.S., Shapiro, A., Meyer, V., Ferraz, A., Yang, Y., Bastin, J.F., Banks, N., Boeckx, P., Verbeeck, H., Lewis, S.L., Muanza, E.T., Bongwele, E., Kayembe, F., Mbenza, D., Kalau, L., Mukendi, F., Ilunga, F., Ebuta, D., 2017. Spatial distribution of carbon stored in forests of the democratic republic of congo. Sci. Rep. 7 https://doi. org/10.1038/s41598-017-15050-Z.

Zhu, Z., 2017. Change detection using landsat time series: A review of frequencies, preprocessing, algorithms, and applications. ISPRS J. Photogramm. Remote Sens. https://doi.org/10.1016/j.isprsjprs.2017.06.013. 